\title{
Evaluation of Neutron Dosimetry Techniques for Well-Logging Operations
}

Prepared by F. M. Cummings, D. L. Haggard, G. W. R. Endres

Pacific Northwest Laboratory Operated by

Battelle Memorial Institute

Prepared for U.S. Nuclear Regulatory Commission 


\section{NOTICE}

This report was prepared as an account of work sponsored by an agency of the United States Government. Neither the United States Government nor any agency thereof, or any of their employees, makes any warranty, expressed or implied, or assumes any legal liability of responsibility for any third party's use, or the results of such use, of any information, apparatus. product or process disclosed in this report, or represents that its use by such third party would not infringe privately owned rights.

\section{NOTICE}

Availability of Reference Materials Cited in NRC Publications

Most documents cited in NRC publications will be available from one of the following sources:

1. The NRC Public Document Room, 1717 H Street, N.W.

Washington, DC 20555

2. The Superintendent of Documents, U.S. Government Printing Office, Post Office Box 37082 , Washington, DC 20013-7082

3. The National Technical Information Service, Springfield, VA 22161

Although the listing that follows represents the majority of documents cited in NRC publications, it is not intended to be exhaustive.

Referenced documents available for inspection and copying for a fee from the NRC Public Document Room include NRC correspondence and internal NRC memoranda; NAC Office of Inspection and Enforcement bulletins, circulars, information notices, inspection and investigation notices; Licensee Event Reports; vendor reports and correspondence; Commission papers; and applicant and licensee documents and correspondence.

The following documents in the NUREG series are available for purchase from the NRC/GPO Sales Program: formal NRC staff and contractor reports, NRC-sponsored conference proceedings, and NRC booklets and brochures. Also available are Regulatory Guides, NRC regulations in the Code of Federal Regulations, and Nuclear Regulatory Commission /ssuances.

Documents available from the National Technical Information Service include NUREG series reports and technical reports prepared by other federal agencies and reports prepared by the Atomic Energy Commission, forerunner agency to the Nuclear Regulatory Commission.

Documents available from public and special technical libraries include all open literature items, such as books, journal and periodical articles, and transactions. Federal Register notices, federal and state legislation, and congressional reports can usually be obtained from these libraries.

Documents such as theses, dissertations, foreign reports and translations, and non-NRC conference proceedings are available for purchase from the organization sponsoring the publication cited.

Single copies of NRC draft reports are available free, to the extent of supply, upon written request to the Division of Technical Information and Document Control, U.S. Nuclear Regulatory Commission, Washington, DC 20555.

Copies of industry codes and standards used in a substantive manner in the NRC regulatory process are maintained at the NRC Library, 7920 Norfolk Avenue, Bethesda, Maryland, and are available there for reference use by the public. Codes and standards are usually copyrighted and may be purchased from the originating organization or, if they are American National Standards, from the American National Standards Institute, 1430 Broadway, New York, NY 10018. 
NUREG/CR-3609

PNL-4942

$\mathrm{RL}, \mathrm{RH}$

\section{Evaluation of Neutron Dosimetry Techniques for Well-Logging Operations}

Manuscript Completed: June 1985

Date Published: July 1985

Prepared by

F. M. Cummings, D. L. Haggard, G. W. R. Endres

Pacific Northwest Laboratory

Richland, WA 99352

\section{Prepared for}

Division of Facility Operations

Office of Nuclear Regulatory Research

U.S. Nuclear Regulatory Commission

Washington, D.C. 20555

NRC FIN 02282 

Neutron dose and energy spectral measurements were performed at a welllogging laboratory using neutron sources typical to well-logging applications. The two neutron sources included $241 \mathrm{AmBe}$ and a small neutron generator which produced $14-\mathrm{MeV}$ neutrons by the following reaction: $T(D, n) 4 \mathrm{He}$. The types of measurements which were performed included neutron absorbed dose measurements using a tissue equivalent proportional counter (TEPC); neutron energy spectrum and flux measurements using a set of multispheres; routine neutron dose equivalent rate monitoring using a cylindrical remmeter and a 10-in. polyethylene ball representing g-in. remballs; measurements using personnel neutron dosimeters. The purpose of the measurements was to determine the most appropriate types of personnel dosimeter and calibration techniques for use in welllogging applications. The dosimeters evaluated included: a photographic film dosimeter, a TLD-albedo dosimeter, a CR-39/TLD combination dosimeter, and polycarbonate track etch film dosimeters.

The dosimeter irradiations were performed on water-filled phantoms at a well-logging laboratory and significantly higher levels of neutron dose equivalent than would normally be received by workers in well-logging operations. These techniques were used to achieve the control necessary to obtain statistically significant results. The irradiations were performed outside in order to gain some degree of simulation of the irradiation conditions encountered in the field.

The source configurations which were investigated included the following:

- $241 \mathrm{AmBe}$ source in the shipping cask

- $241 \mathrm{AmBe}$ source in air

- $241 \mathrm{AmBe}$ source in well-logging tool

- $241 \mathrm{AmBe}$ source in well-logging tool calibrator

- Neutron generator in the calibration tank

- Neutron generator in air.

of the dosimeters which were evaluated, the dosimeter which was recommended to be most appropriate for well-logging application was the TLD-albedo.

The TLD-albedo dosimeter result was higher than the delivered dose equivalent in each of the irradiation geometries. The neutron dose equivalent determined using the TLD-albedo dosimeter was greater than the delivered neutron dose equivalent because: (1) a sufficient number of neutrons of lower energy were present to raise the TL0-albedo result and (2) the TLD-albedo dosimeter did not suffer from energy-cutoff problems.

The type of source which was judged to be most appropriate for calibrating dosimeters used in well-logging applications was the unmoderated source normally used by the personnel performing well-logging operations. 


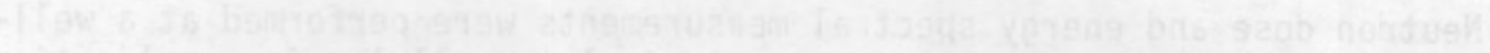

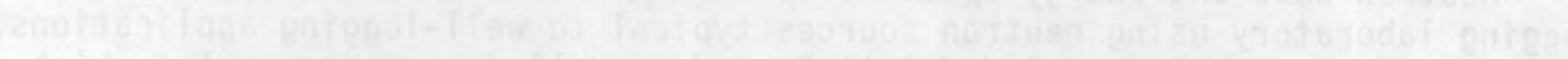
Whathe

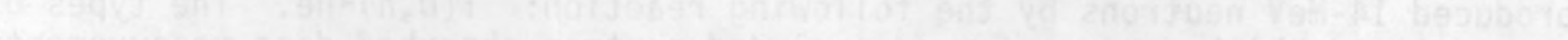

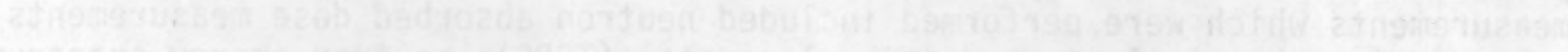

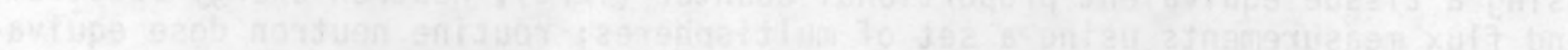

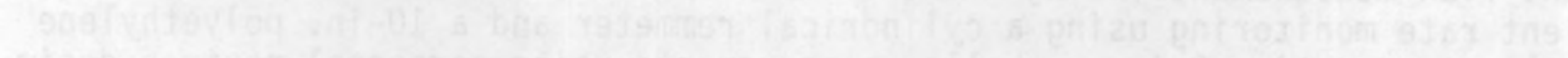

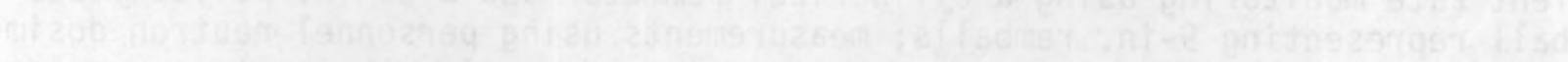

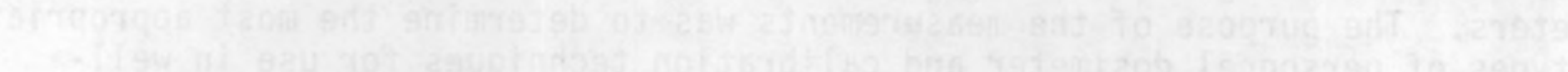
210

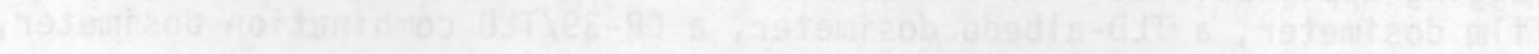

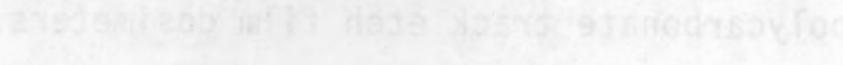

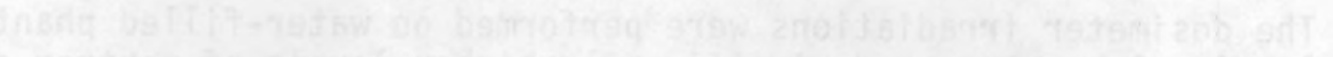

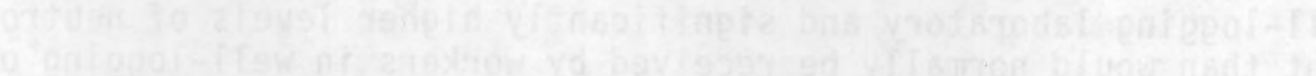

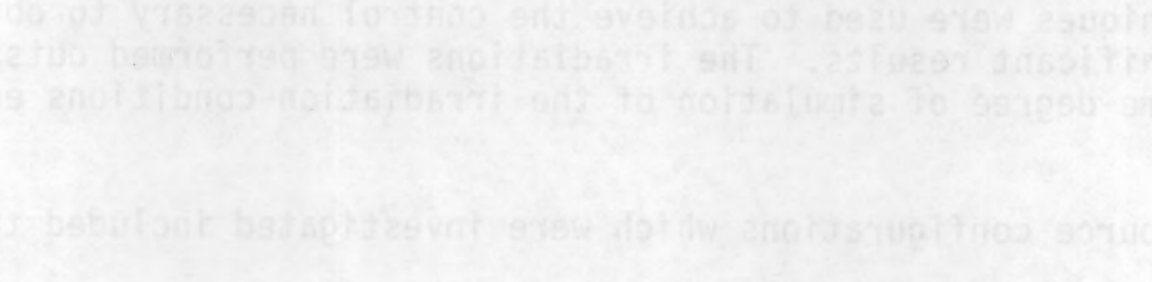


Neutron dose and energy spectral measurements were performed at a welllogging laboratory using neutron sources typical to well-logging applications. The two neutron sources included ${ }^{241} \mathrm{AmBe}$ and a small neutron generator which produced $14 \mathrm{MeV}$ neutrons by the following reaction: T(D,n) 4 He. The types of measurements which were performed included neutron absorbed dose measurements using a tissue equivalent proportional counter (TEPC); neutron energy spectrum and flux measurements using a set of multispheres; routine neutron dose equivalent rate monitoring using a cylindrical remmeter and a $10-i n$. polyethylene ball representing 9-in. remballs; measurements using personnel neutron dosimeters. The purpose of the measurements was to determine the appropriate types of personnel dosimeter and calibration techniques for use in well-logging applications. The dosimeters evaluated include: a photographic film dosimeter, a TLD-albedo dosimeter, a CR-39/TLD combination dosimeter, and a polycarbonate track etch film dosimeter.

The dosimeter irradiations were performed on water-filled phantoms at a well-logging laboratory and to significantly higher levels of neutron dose equivalent than would normally be received by workers in well-logging operations. These techniques were used to achieve the control necessary to obtain statistically significant results. The irradiations were performed outside in order to gain some degree of simulation of the irradiation conditions encountered in the field.

The source configurations which were investigated included the following:

- ${ }^{241} \mathrm{AmBe}$ source in the shipping cask

- ${ }^{241} \mathrm{AmBe}$ source in air

- ${ }^{241}$ AmBe source in the well-logging tool

- ${ }^{241} \mathrm{AmBe}$ source in the well-logging tool calibrator

- Neutron generator in the calibration tank

- Neutron generator in air.

All of the dosimeters except the TLD-albedo exhibited low average responses (i.e. the ratio of the average response of the dosimeters irradiated in a certain geometry to the reference neutron dose equivalent was less than unity) for at least one of the irradiation geometries. The low response was due to the inability of the dosimeters to adequately measure dose equivalent from neutrons with energies below a certain point. That point was designated as the energy-cutoff. The measurement technique used to determine the reference neutron dose equivalent was based upon analysis of data from a tissue equivalent proportional counter. A cylindrical remmeter was used to determine neutron dose equivalent rates, and since it exhibited close agreement with the reference measurements and is readily available on the open market, dosimeter results were also compared to the remmeter results. The TLD-albedo dosimeter was judged to be the most appropriate type personnel neutron dosimeter among those dosimeters which were evaluated in this study.

The appropriate calibration source for both the dosimeters and the remmeter was judged to be the source in use at the time of irradiation. The 
appropriate geometry for calibration includes using the unmoderated source in a low to medium scatter environment with dosimeters irradiated on phantoms.

All of the dosimeters exhibited pronounced energy dependence for the source geometries used in this study. Because of that energy dependence, no single calibration factor will allow for the accurate assessment of the neutron dose equivalent delivered to a dosimeter (or personnel wearing the dosimeter) for all the situations. It is not recommended that dosimeter results be adjusted to account for spectral differences because of the following reasons: (1) large errors in dosimeter results may be introduced due to inaccurate estimates of irradiation times for a given geometry, (2) small dose equivalents with proportionately larger error would be impacted by the use of the adjustment factor, and (3) it would be difficult to ascertain how closely field situations were actually simulated in this study and what differences would be expected in different irradiation geometries. 


\section{CONTENTS}

ABSTRACT • • • • • • • • • • •

SUMMARY

ACKNOWLEDGMENTS

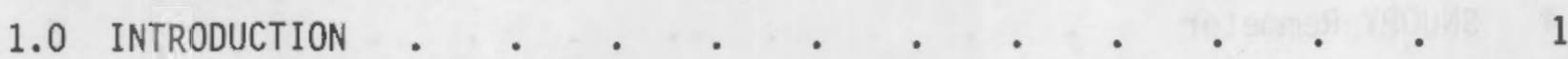

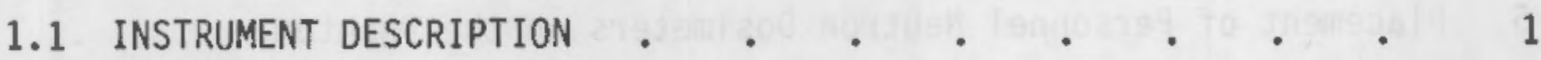

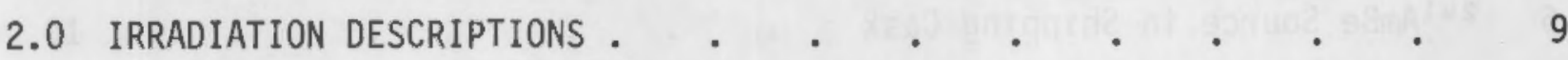

$2.1241 \mathrm{AmBe}$ IN SHIPPING CASK $~ . \quad \ldots \quad . \quad \ldots \quad . \quad$. $\quad . \quad 9$

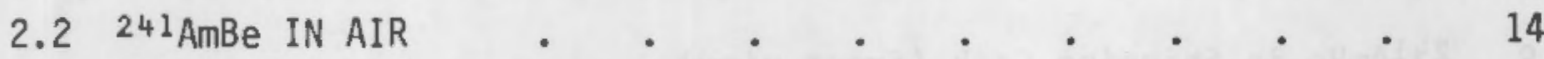

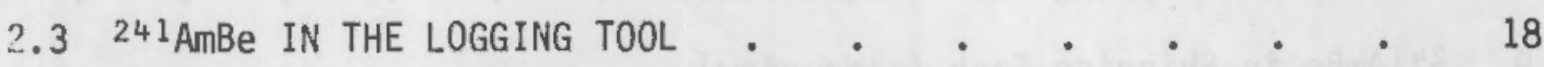

$2.4241 \mathrm{AmBe}$ IN THE LOGGING TOOL CALIBRATOR SLEEVE $\quad$ • . $\quad 23$

2.5 NEUTRON GENERATOR IN THE SAND/WATER CALIBRATION TANK $\quad$ • $\quad 29$

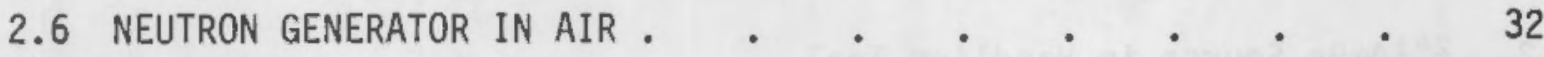

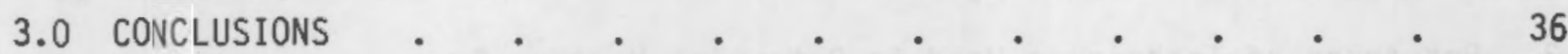

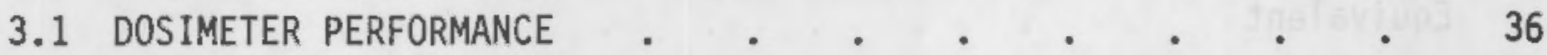

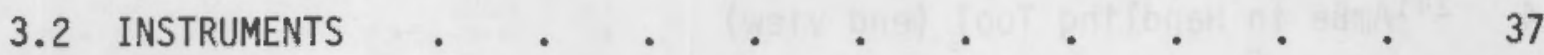

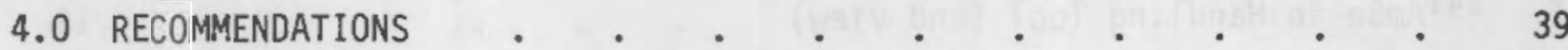

5.0 REFERENCES . . . . . . . . . . . . . 40 


\section{FIGURES}

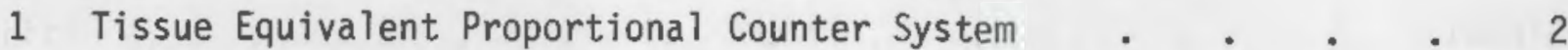

2 Tissue Equivalent Proportional Counter Construction . . . 3

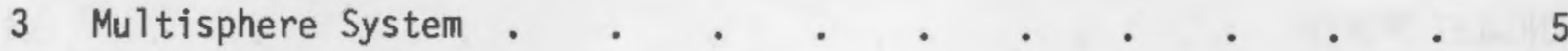

4 SNOOPY Remmeter . . . . . . . . . . . . . 6

5 Placement of Personnel Neutron Dosimeters on the Phantom . $\quad 7$

$6 \quad 241 \mathrm{AmBe}$ Source in Shipping Cask . . . . . . . . 10

7 Responses of Techniques Used to Determine Neutron Dose

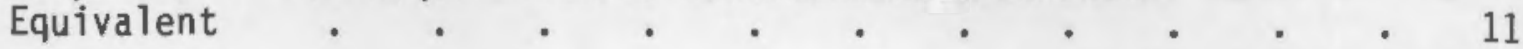

$8 \quad 241 \mathrm{AmBe}$ in Shipping Cask (front view) . . . . . . . . 12

$9 \quad{ }^{241} \mathrm{AmBe}$ in Shipping Cask (side view) . . . . . . $\quad 13$

$10 \quad{ }^{241} \mathrm{AmBe}$ in Shipping Cask (front view) . . . . . . . 13

$11{ }^{241} \mathrm{AmBe}$ in Shipping Cask (side view) . $\quad . \quad$. $\quad . \quad$. $\quad 14$

$12{ }^{241}$ AmBe Source in Handling Tool $\quad$. $\quad . \quad$. $\quad . \quad$. 15

13 Responses of Techniques Used to Determine Neutron Dose

$14 \quad 241 \mathrm{AmBe}$ in Handling Tool (end view) . . . . . . 17

$15 \quad 241 \mathrm{AmBe}$ in Handling Tool (end view) . $\quad . \quad$. $\quad . \quad$. 18

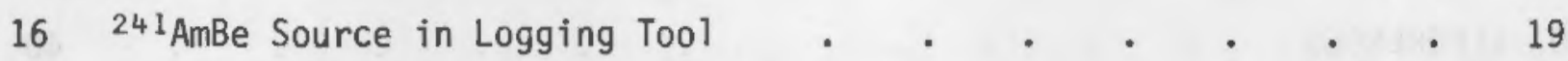

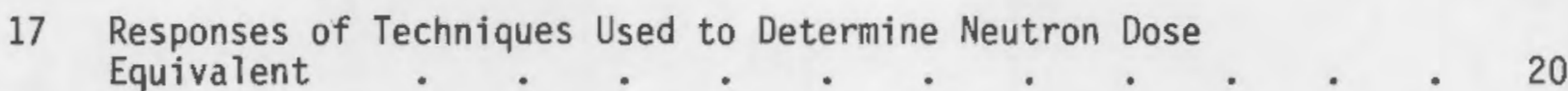

$18{ }^{241} \mathrm{AmBe}$ in Logging Tool (side view) . . . . . . . 21

$19 \quad{ }^{241}$ AmBe in Logging Tool (end view) . . . . . . . . 22

$20 \quad{ }^{241} \mathrm{AmBe}$ in Logging Tool (side view) . . . . . . . 22

$21 \quad{ }^{241} \mathrm{AmBe}$ in Logging Tool (end view) . . . . . . . . 23

$22{ }^{24 l} \mathrm{AmBe}$ in Plastic Calibrator Sleeve $. \quad . \quad . \quad . \quad . \quad$. 24

\begin{tabular}{l} 
Responses of Techniques Used to Determine Neutron Dose \\
Equivalent \\
\hline
\end{tabular} 
$24{ }^{241}$ AmBe in Logging Tool Calibrator Sleeve (side view) . . . 26

$25{ }^{241}$ AmBe in Logging Tool Calibrator Sleeve (end view) . . 27

$26{ }^{241}$ AmBe in Logging Tool Calibrator Sleeve (side view) . . . 27

$27{ }^{241} \mathrm{AmBe}$ in Logging Tool Calibrator Sleeve (end view) . . . 28

28 Neutron Generator in Sand/Water Calibration Tank . . . 30

29 Responses of Techniques Used to Determine Neutron Dose

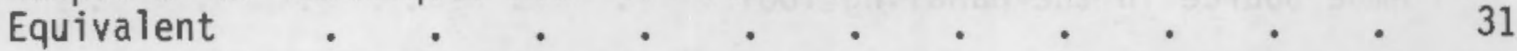

30 DT Generator in Calibrator Tank (side view) . . . . . 32

31 DT Generator in Calibrator Tank (front view) . . . . . 33

32 DT Generator in Calibrator Tank (side view) . . . . 33

33 DT Generator in Calibrator Tank (front view) . . . . . 34

34 DT Generator (in air) . . . . . . . . . 34

35 DT Generator (in air) . . . . . . . 35 


\section{TABLES}

1 Neutron Dose Equivalents for the Side Orientation of the ${ }^{241} \mathrm{AmBe}$ Source in the Shipping Cask . . . .

2 Neutron Dose Equivalent Rates for the ${ }^{241}$ AmBe Source in

3 Neutron Dose Equivalents for the Side Orientation of the ${ }^{241} \mathrm{AmBe}$ Source in the Handling Tool . . . . . . 16

4 Neutron Dose Equivalent Rates for the ${ }^{241}$ AmBe Source

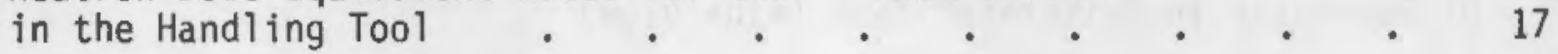

5 Neutron Dose Equivalents for the Side Orientation of the ${ }^{241}$ AmBe Source in the Logging Tool . . . . . . . 20

6 Neutron Dose Equivalent Rates for the ${ }^{241} \mathrm{AmBe}$ Source in the Logging Too1 . . . . . . . . . . 21

7 Neutron Dose Equivalents for the Side Orientation of the ${ }^{241}$ AmBe Source in the Logging Tool Calibrator Sleeve . . . 25

8 Neutron Dose Equivalent Rates for the Side Orientation of the ${ }^{241} \mathrm{AmBe}$ Source in the Logging Tool Calibrator Sleeve . . .

g Neutron Dose Equivalents for the Side Orientation of the Neutron Generator in the Sand/Water Calibration Tank . . . 29

1D Neutron Dose Equivalent Rates for the Side Orientation of the Neutron Generator in the Sand/Water Calibration Tank .

11 Neutron Dose Equivalent Rates for the Neutron Generator in Air . . . . . . . . . . . . 32

12 Summary of Dosimeter Response Ratios . . . . . . 36

13 Summary of Ins.trument Response Ratios . • • • • • 37

14 Summary of "Recalibrated" Instrument Response Ratios . . . 38 


\section{ACKNOWLEDGMENTS}

The authors wish to thank Ed Mott, Dave Norman, Jack Lee, and John McClellan of Dresser Industries and George 0'Bannion of Nuclear Sources and Services for their valuable help and consultation throughout this project. We also wish to thank Craig Yoder and Greg Macievic of R. S. Landauer and $\mathrm{Mr}$. O'Bannion for providing dosimeters and dosimeter readout. Additionally, many thanks to Marianna Cross for typing and proofing the report. 



\subsection{INTRODUCTION}

This study is part of a continuing project, funded by the U.S. Nuclear Regulatory Commission (NRC) to evaluate personnel neutron dosimetry at licensed facilities. This task was initiated to verify the adequacy of personnel neutron dosimetry and calibration techniques currently in use by welllogging licensees.

The neutron sources generally used for well-logging applications include $241 \mathrm{AmBe}$ and $14 \mathrm{MeV}$ neutron generators. The irradiations in this study were performed using these two sources. The source strength of the $241 \mathrm{AmBe}$ was $18 \mathrm{Ci}$ and the neutron emission rate was $4 \times 10^{7}$ neutrons/sec. The generator was a small grid type accelerator which accelerated deuterium atoms into a tritiated target producing $14-\mathrm{MeV}$ neutrons. The neutron emission rate was approximately $10^{8}$ neutrons/sec.

\subsection{INSTRUMENT DESCRIPTION}

The instruments used in this study have been well documented in the literature and will be described in this report in cursory fashion only. The reader is directed to other reports produced in support of this project (NUREG/CR-1769 and NUREG/CR-2956) and to the reference lists in those reports for more detailed descriptions of the various instruments and measurement techniques.

The tissue equivalent proportional counter system (TEPC) was used to measure neutron absorbed doses and determine neutron dose equivalent (and the associated rates) because the TEPC: (1) is the only available instrument which directly measures neutron absorbed dose, (2) has produced dose equivalent results which are in close agreement with well characterized neutron fields produced at several facilities, and ( 3 ) is independent of neutron energies in the range of neutron energies encountered in this report. A cylindrical remmeter, designated as SNOOPY, was used to monitor dose equivalent rates and personnel neutron dosimeters were irradiated to evaluate the response of the dosimeters to neutrons produced by the well-logging sources. Average neutron energies and neutron energy spectra were determined using a set of multispheres.

The TEPC (shown in Figure 1) was a 5-in. diameter spherical proportional counter. The theory of operation may be summarized as follows (refer to Figure 2): A neutron interacts with the plastic wall (Shonka A-150 plastic) of the counter creating a secondary charged particle (i.e., recoil proton, alpha, or heavy ion). As the charged particle traverses the counter, it ionizes the atoms of the filling gas (propane based tissue equivalent gas). The electrons which are stripped from the ions are accelerated toward the collecting anode. As the electrons travel toward the anode, they ionize other gas atoms creating an avalanche of electrons. The number of electrons collected at the anode is proportional to the energy deposited in the gas by the passage of the original secondary charged particle. So, the TEPC measures absorbed dose (to a small volume) directly. Pulses, or signals, are amplified and stored in a multichannel analyzer (MCA) (Figure 1). Analys is of data 


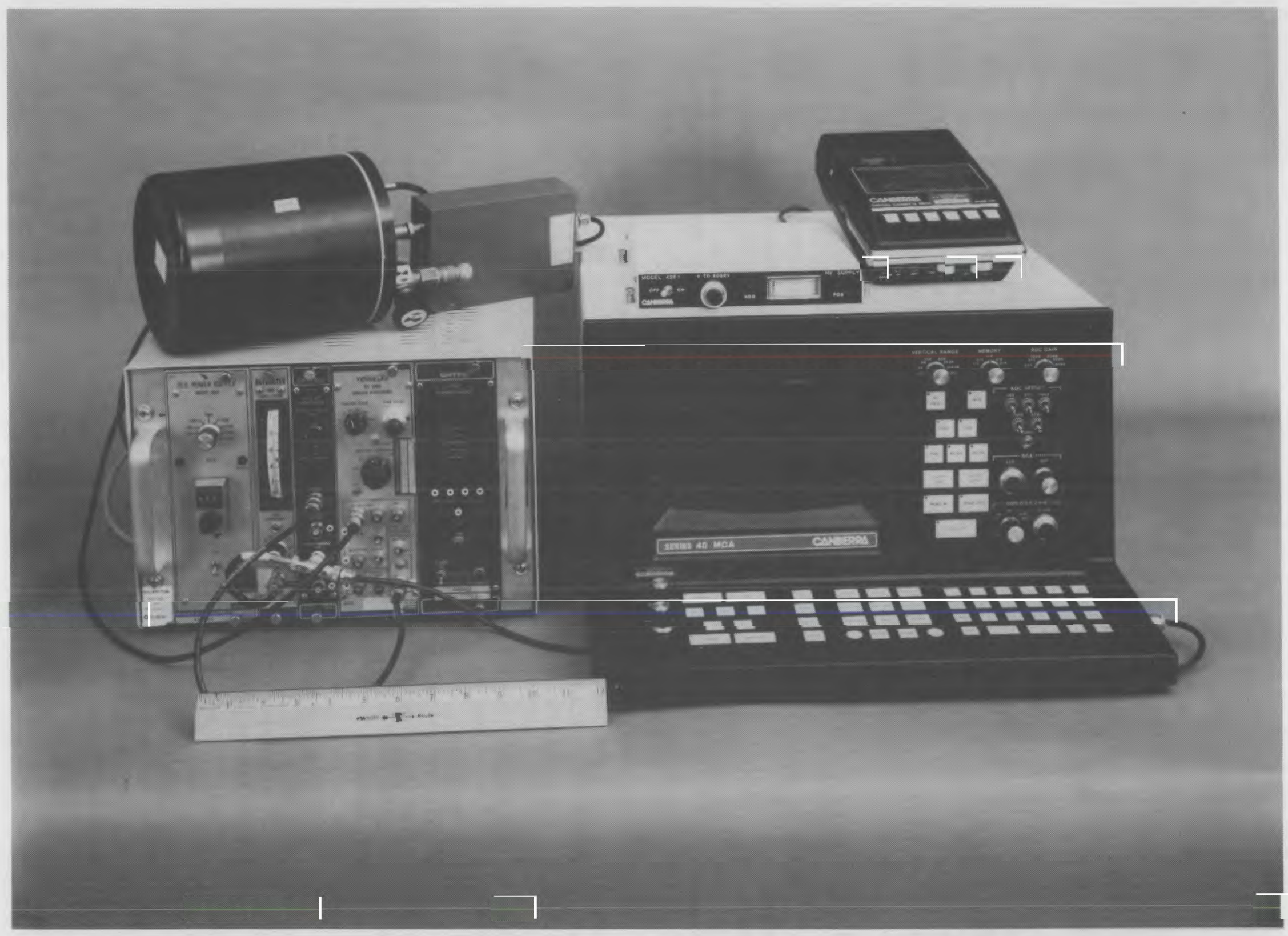

FIGURE 1. Tissue Equivalent Proportional Counter System 


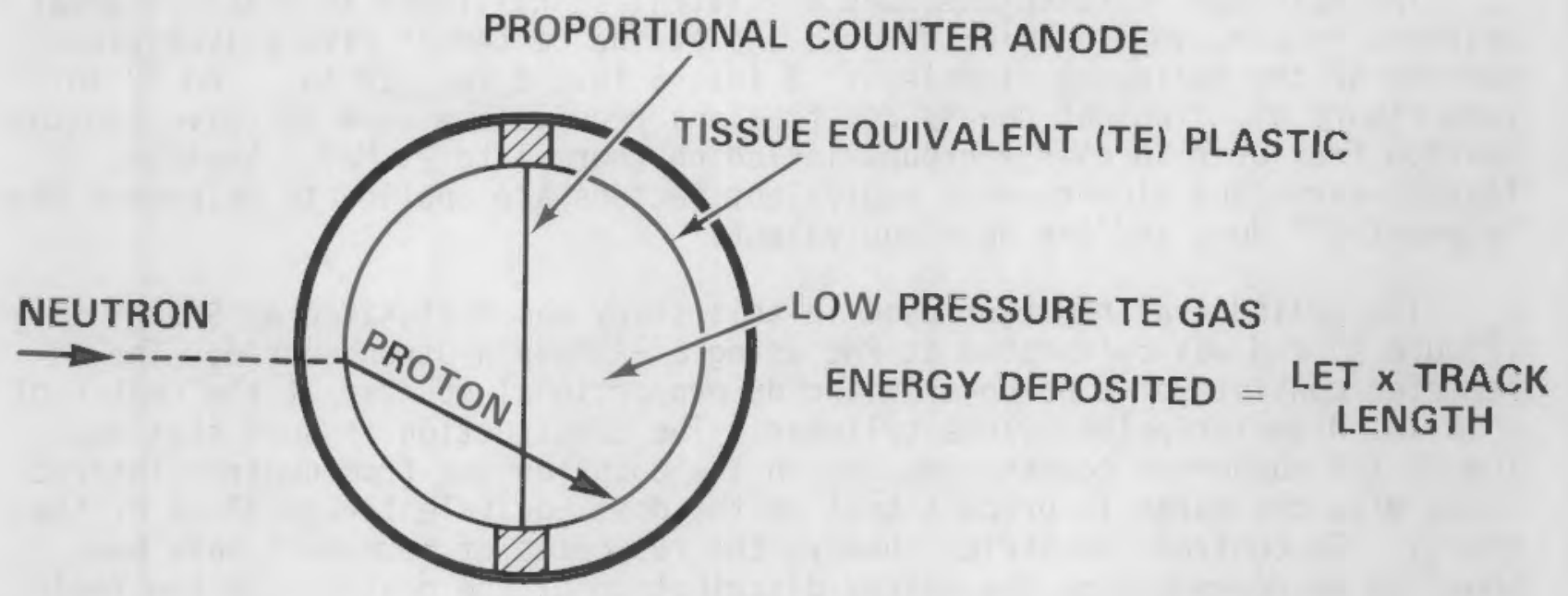

FIGURE 2. Tissue Equivalent Proportion Counter Construction

depends on accurately determining the proton drop point, the point which represents the maximum amount of energy a proton can deposit in the gas as it traverses the diameter of the counter. The neutron absorbed dose is proportional to the sum of the product of the counts in a given channel (of the MCA) and the channel number over the range of lineal energies attributed to neutron interactions. That is:

$$
D=1.602 \times 10^{-8} \times \sum_{h 1}^{h 2} C \times h \times N(h) \times(V)^{-1} \times(\rho)^{-1}
$$

(ICRU 1977)

where $\quad D=$ neutron absorbed dose, rad

$\mathrm{C}=$ conversion factor for channel to $\mathrm{keV}$

$\mathrm{h}=$ channe $]$

$N(h)=$ counts in channel $h$

hl = starting channel

h2 = ending channel

$V=$ counter volume, $\mathrm{cm}^{3}$

$\rho=$ filling gas density, $\mathrm{g} / \mathrm{cm}^{3}$.

The quality factor is determined from the distribution of lineal energies (signal pulse heights) by assuming that the average lineal energy is $9 / 8$ the corresponding average linear energy transfer and solving the following 4 th order polynomial (equation 2). The dose equivalent is the sum of the products of dose event and quality factor.

$$
\begin{aligned}
\text { Quality Factor }= & -7.168(\ln (L))+12.409(\ln (L))-7.726(\ln (L))^{2} \\
& +1.9(\ln (L)))^{3}-0.15(\ln (L))^{4}
\end{aligned}
$$

where $\operatorname{Ln}(L)$ is the natural logarithm of $8 / 9$ times the average lineal energy. 
The multisphere technique uses a ${ }^{6} \mathrm{LiI}(\mathrm{Eu})$ scintillator to detect thermal neutrons in air, in a cadmium sleeve, and at the center of five polyethylene spheres of the following diameters: $3 \mathrm{in.,} 5 \mathrm{in.,} 8 \mathrm{in.,} 10 \mathrm{in.,}$ and $12 \mathrm{in.}$ (see Figure 3 ). The net counts due to alpha recoils are used to solve for the neutron flux over 26 energy groups including thermal to $20 \mathrm{MeV}$. Neutron flux-to-kerma and flux-to-dose equivalent factors are applied to determine the "element-57" dose and the dose equivalent.

The cylindrical remmeter used in this study was designated as SNOOPY (Figure 4) and was calibrated at PNL using a $239 \mathrm{PuBe}$ neutron source. The remmeter consists of a boron-trifluoride proportional counter at the center of a 15-in. diameter polyethylene cylinder. The construction is such that in theory the number of counts produced in the counting gas from neutron interactions with the boron is proportional to the dose equivalent regardless of the energy. In contrast to strict theory, the responses of remmeters have been shown to be dependent on the energy distribution of the neutrons in the field being measured (Cosack and Lesiecki 1981). In this study, it was concluded that the cylindrical remmeter, calibrated using $239 \mathrm{puBe}$, responded closely to reference values because of the relative hardness of the overall neutron spectra and because the remmeter response varies slowly in the region of neutron energies encountered using the ${ }^{241} \mathrm{AmBe}$ source in the various configurations.

The 10-in. sphere response from the multisphere set was taken as representative of the response of the 9-in. remballs currently commercially available. The justification for this assumption comes from a study performed by Hankins in 1967 (Hankins 1968) in which the differences in responses of a LiI crystal were compared to the responses of a $\mathrm{BF}_{3}$ tube in 9-in. and 10-in. spheres (similar to the ones used in this study). The report concluded that the responses of the four types of instruments were within counting accuracy of the detectors. For this reason, the 10-in. sphere may be assumed to be representative of the $9-i n$. remballs. The net count rate due to neutron interactions in the LiI crystal was multiplied by a factor to convert from count/second to mrem/hour. The calibration constant was determined using a bare ${ }^{252} \mathrm{Cf}$ source to be 0.10547 mrem-sec/counts-hour. The ${ }^{252} \mathrm{Cf}$ source was chosen as a calibration source due to its availability and its use in the radiation instrumentation industry as a calibration source. In this report, 10 -in. remball results will be designated as "RB10."

The types of personnel dosimeters which were evaluated in the various source configurations included photographic film (Kodak NTA), TLD-albedo (using ${ }^{6} \mathrm{LiF}$ ), and $\mathrm{CR}-39$ and polycarbonate track etch films. All irradiations were performed on a 5-gallon plastic water phantom and dosimeters were placed on the phantom so that no part of any particular dosimeter was closer than $10 \mathrm{~cm}$ to the edge of the phantom (see Figure 5). In most cases, 3 dosimeters were irradiated in each configuration in order to provide some measure of the statistical precision of each type of dosimeter. All commercial dosimeters were tested as routinely calibrated by vendors and a brief description of dosimeter and calibration method follows: 


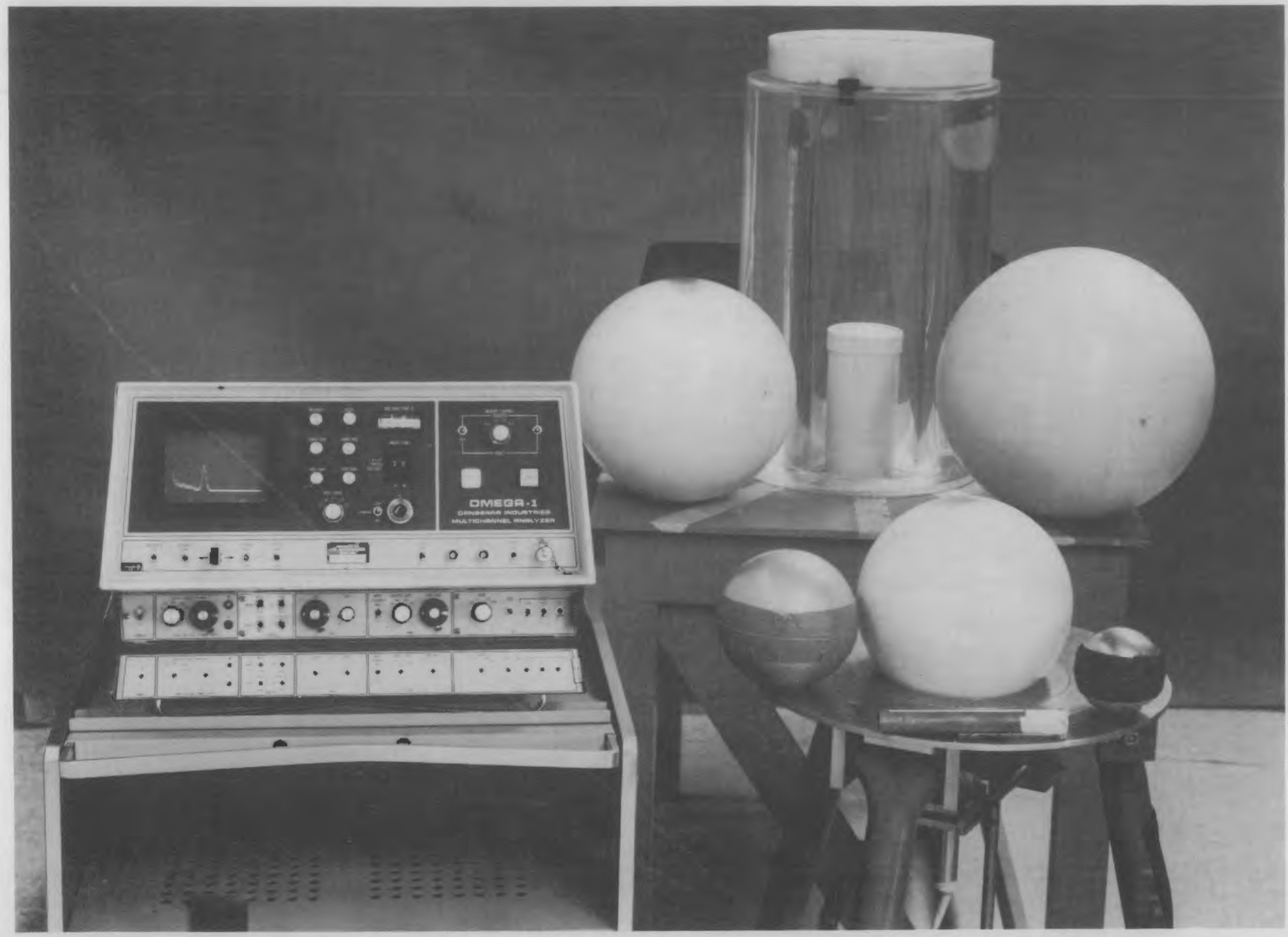

FIGURE 3. Multisphere System 


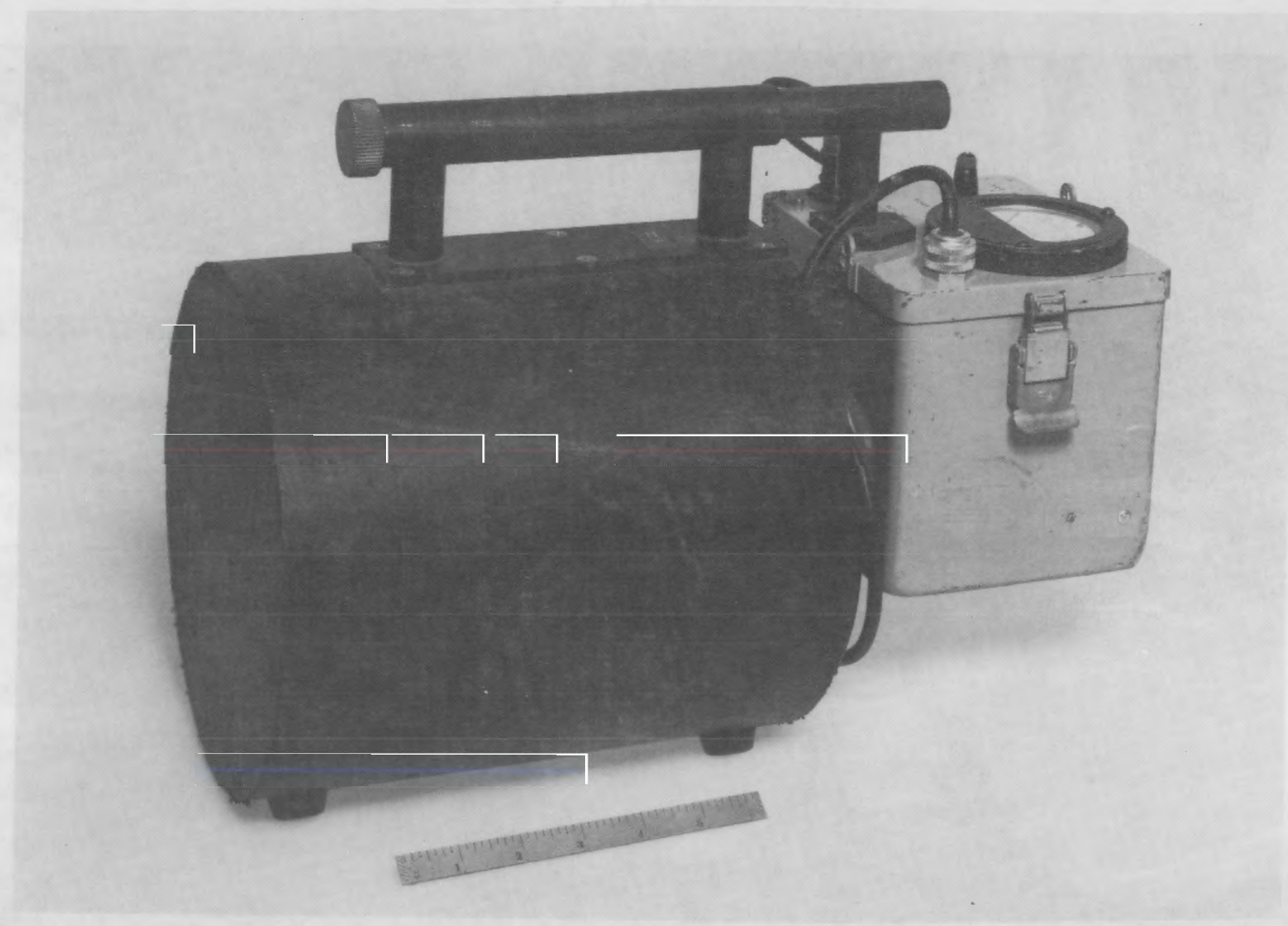

Figure 4. SNOOPY Remmeter 


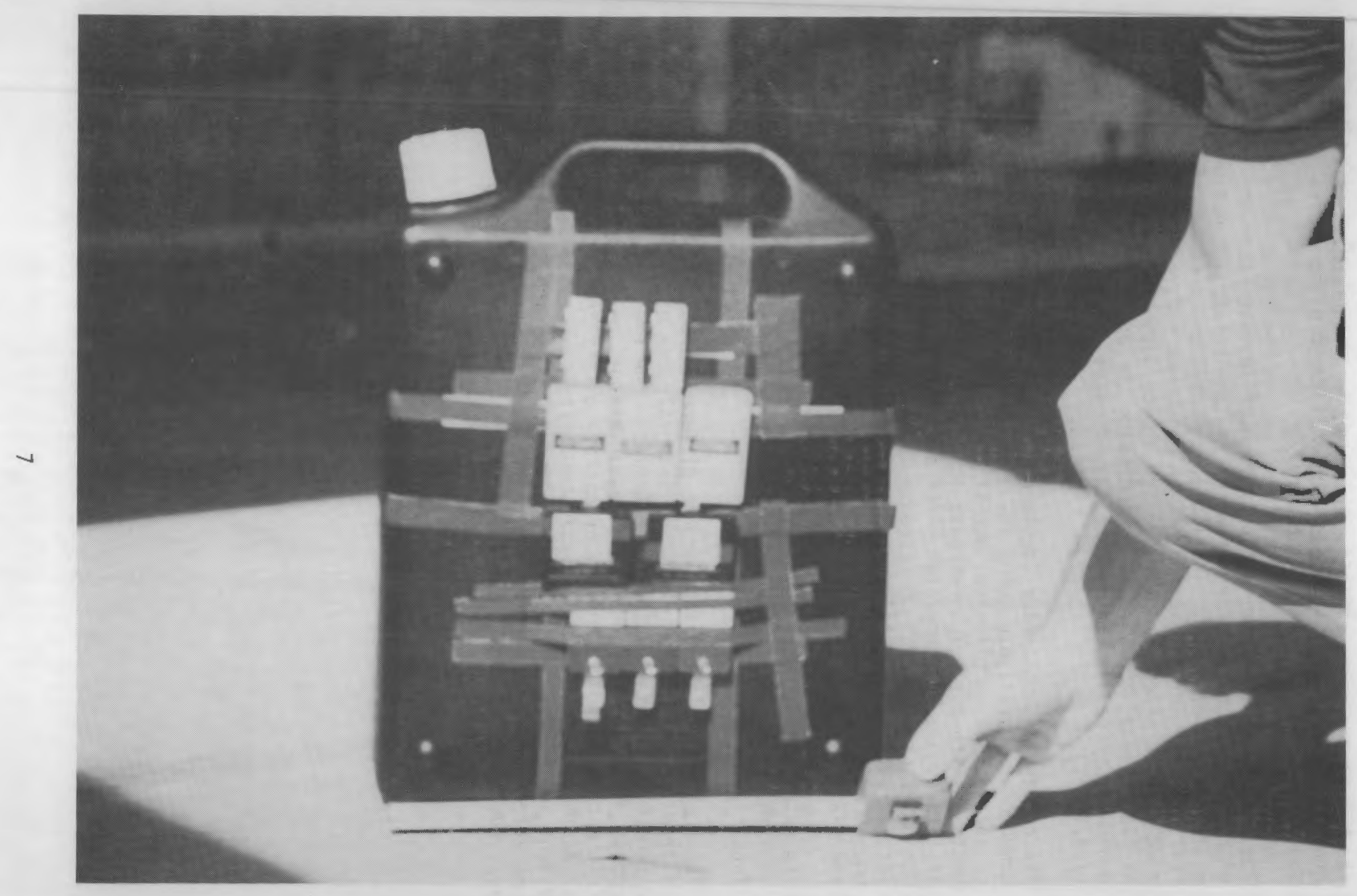

FIGURE 5. Placement of Personnel Neutron Dosimeters on the Phantom 
- The NTA photographic emulsion dosimeter is a standard commercially available film badge which has been calibrated using a bare ${ }^{241} \mathrm{AmBe}$ source in a medium-scatter facility.

- The TLD-albedo dosimeters which were used in this study are dosimeters supplied by a processor which routinely supplies dosimeters to well-logging personnel. The TLD abledo utilizes a combination of ${ }^{6} \mathrm{LiF}$ and $7 \mathrm{LiF}$ for neutron detection and gamma subtraction respectively. The processor-supplied TLD-albedo dosimeter is designated as "TLD-albedo" and was calibrated using the energy response of the dosimeter normalized to ${ }^{241} \mathrm{AmBe}$ (based on an average neutron energy of $4.5 \mathrm{MeV}$ ).

- The combination dosimeter (designated as Comb in the report) is also commercially available using CR-39 and ${ }^{6} \mathrm{LiF}$ in combination. The calibration is complicated, but if the TLD portion of the response dominates, then the TLD response is used to calculate dose equivalent through a $\mathrm{D}_{2} \mathrm{O}$-moderated ${ }^{252} \mathrm{Cf}$ source. If the $\mathrm{CR}-39$ response dominates, then the CR-39 response is used to calculate dose equivalent through a bare ${ }^{241} \mathrm{AmBe}$ calibration. If the two are roughly equal, a factor is used to adjust the albedo response and add it to the CR-39 response to determine dose equivalent.

- The CR-39 and polycarbonate track etch films are commercially available and both were calibrated using bare ${ }^{241} \mathrm{AmBe}$ in a medium-scatter facility.

The dose equivalent rates for the different neutron source configurations varied from 5 to $300 \mathrm{mrem} / \mathrm{hr}$ and the integral dose equivalents delivered to the dosimeters varied from 150 to 4800 mrem. The high dose rates were chosen to produce statistically enhanced doses in a short period of time. There was insufficient time and funding to adequately assess the sensitivity of personnel dosimeters at very low doses/rates. It is expected that the lower dose equivalent and rates to which well-logging personnel are normally exposed will have no adverse effects on the conclusions or recommendations of this report, however, the impact is not known and would require further study. 


\subsection{IRRADIATION DESCRIPTIONS}

Measurements were performed using the neutron sources in various configurations (e.g. bare, in shipping cask, etc.) and for various orientations of the source configurations (i.e. side or end-on orientations). It was thought that the various orientations might provide different neutron energy spectra because of the different amounts and configurations of moderating material. This is the reason that the side and end-on orientations were studied as well as the various source configurations. While the dosimeters were irradiated in each configuration, irradiation time and number of dosimeters limited the irradiations to one orientation (side or end) for each configuration. Measurements are presented for each configuration and orientation, whether dosimeters were irradiated or not. It was determined by the consultants from a major oil services corporation that within the constraints of dose rates, integral doses, and precisions, the irradiation conditions which were studied in this experiment represented the conditions under which well-logging personnel in the field routinely receive neutron dose. The irradiations were all performed outside at a height of slightly more than one meter above the ground. In the irradiations using the ${ }^{241} \mathrm{AmBe}$ source, the ground was covered with a 4-in. concrete pad. Measurements are normalized to the distance between the phantom face and the source for integral dose comparisons. The dose rate measurements are normalized to one meter for comparison of instrument readings.

\section{$2.12{ }^{241} \mathrm{AmBe}$ IN SHIPPING CASK}

Figure 6 shows the multisphere measurement being performed in the side orientation and simultaneous TEPC and ${ }^{3} \mathrm{He}$ measurements being performed in the end-on orientation. The figures which show the irradiations in progress were chosen to be representative of the irradiation conditions. No attempt was made to photograph each irradiation. The TEPC was placed at 23.5 in. from the side of the cask, the multisphere system and the SNOOPY were both at $19.5 \mathrm{in}$. from the side of the cask and the dosimeter phantom was $9.5 \mathrm{in}$. from the side of the cask. The cask was $18.5 \mathrm{in}$. in diameter, so the source to detector distances were calculated by adding $9.25 \mathrm{in}$. to the aforementioned distances. Response ratios for the side orientation measurements are plotted in Figure 7. The reference dose equivalent rates were determined to be $6 \mathrm{mrem} / \mathrm{hr}$ at 1 meter from the source for the side orientation and $14 \mathrm{mrem} / \mathrm{hr}$ at 1 meter from the source for the end-on orientation. The dose equivalent measurements are summarized in Table 1.

The dose equivalent rates determined from the instruments were normalized to 1 meter by the $1 / \mathrm{d}^{2}$ technique. The results appear in Table 2 . It was expected at the time of the irradiations that the neutron energy spectra for the side and end-on orientations would not be significantly different. In fact, the average neutron energies determined from multisphere data were $1.28 \mathrm{MeV}$ for the side orientation and $1.85 \mathrm{MeV}$ for the end-on orientation. Figures 8 through 11 are plots of the neutron flux and dose equivalent spectra determined from multisphere data. The reasons for the higher average neutron energy for the end-on orientation is due to the lack of moderation around the source while it is in the cask cavity. The neutrons emerging from the side 


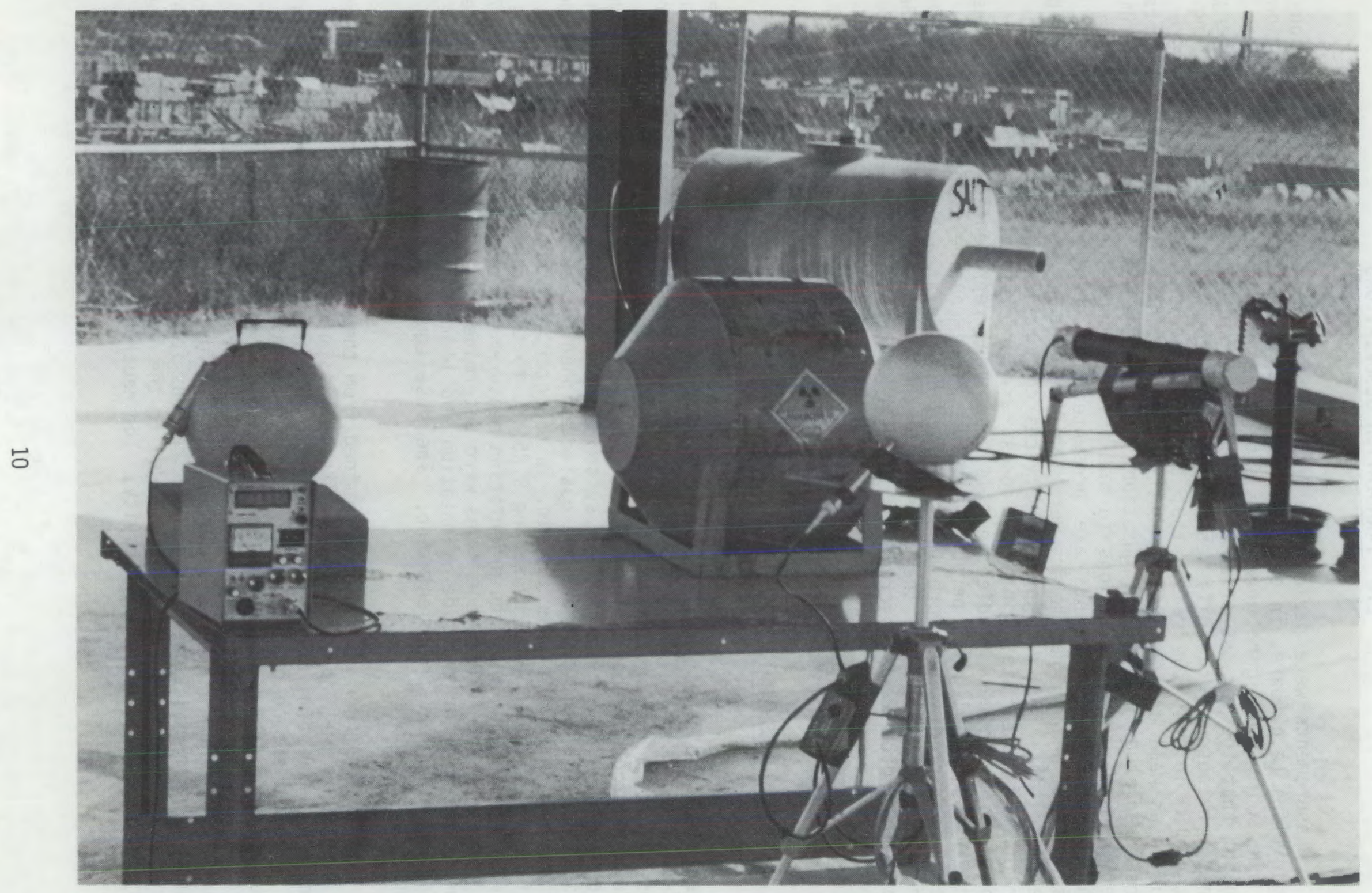

FIGURE 6. ${ }^{241} \mathrm{AmBe}$ Source in Shipping Cask 


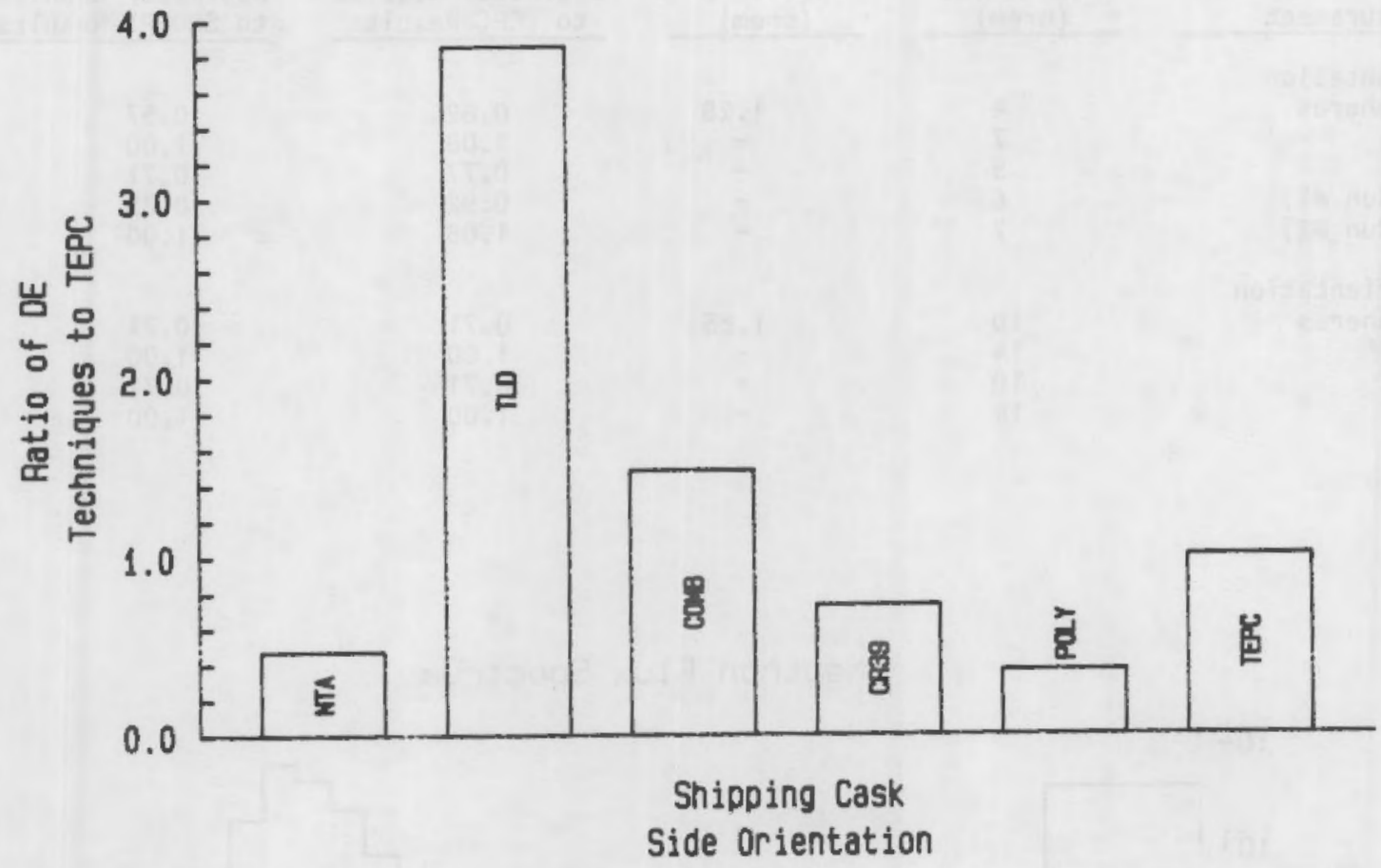

FIGURE 7. Responses of Techniques Used to Determine Neutron Dose Equivalent

TABLE 1. Neutron Dose Equivalent Results for the Side Orientation of the ${ }^{241} \mathrm{AmBe}$ Source in the Shipping Cask

\begin{tabular}{|c|c|c|c|c|}
\hline Measurement & $\begin{array}{c}\begin{array}{c}\text { Average Dose } \\
\text { Equivalent } \\
\text { (mrem) }\end{array} \\
\end{array}$ & $\begin{array}{c}\text { One Standard } \\
\text { Deviation } \\
\text { (mrem) } \\
\end{array}$ & $\begin{array}{c}\quad \text { Ratio of } \\
\text { Dosimeter Results } \\
\text { to TEPC Results } \\
\end{array}$ & $\begin{array}{l}\quad \text { Ratio of } \\
\text { Dosimeter Results } \\
\text { to SNOOPY Results } \\
\end{array}$ \\
\hline NTA Film Dosimeter & 58 & 15 & 0.47 & 0.44 \\
\hline HMPD TLD-albedo & 116 & 42 & 0.94 & 0.87 \\
\hline TLD-albedo Dosimeter & 478 & 43 & 3.85 & 3.57 \\
\hline Combination Dosimeter & 183 & 23 & 1.48 & 1.38 \\
\hline CR-39 Dosimeter & 91 & 18 & 0.73 & 0.68 \\
\hline Poly Dosimeter & 45 & 7 & 0.36 & 0.33 \\
\hline
\end{tabular}


TABLE 2. Neutron Dose Equivalent Rates for the ${ }^{241}$ AmBe Source in the Shipping Cask

\begin{tabular}{|c|c|c|c|c|}
\hline Measurement & $\begin{array}{c}\text { Average Dose } \\
\text { Equivalent } \\
\text { (mrem) } \\
\end{array}$ & $\begin{array}{c}\text { One Standard } \\
\text { Deviation } \\
\text { (mrem) } \\
\end{array}$ & $\begin{array}{l}\text { Ratio of } \\
\text { Dosimeter Results } \\
\text { to TEPC Results } \\
\end{array}$ & $\begin{array}{l}\quad \text { Ratio of } \\
\text { Dosimeter Results } \\
\text { to SNOOPY Results } \\
\end{array}$ \\
\hline $\begin{array}{l}\text { Side Orientation } \\
\text { Multispheres } \\
\text { SNOOPY } \\
\text { RB10 } \\
\text { TEPC (Run \#1) } \\
\text { TEPC (Run } \# 2 \text { ) }\end{array}$ & $\begin{array}{l}4 \\
7 \\
5 \\
6 \\
7\end{array}$ & $\begin{array}{l}1.28 \\
- \\
= \\
-\end{array}$ & $\begin{array}{l}0.62 \\
1.08 \\
0.77 \\
0.92 \\
1.08\end{array}$ & $\begin{array}{l}0.57 \\
1.00 \\
0.71 \\
0.85 \\
1.00\end{array}$ \\
\hline $\begin{array}{l}\text { End-On Orientation } \\
\text { Multispheres } \\
\text { SNOOPY } \\
\text { RB10 } \\
\text { TEPC }\end{array}$ & $\begin{array}{l}10 \\
14 \\
10 \\
14\end{array}$ & $\begin{array}{l}1.85 \\
- \\
-\end{array}$ & $\begin{array}{l}0.71 \\
1.00 \\
0.71 \\
1.00\end{array}$ & $\begin{array}{l}0.71 \\
1.00 \\
0.71 \\
1.00\end{array}$ \\
\hline
\end{tabular}

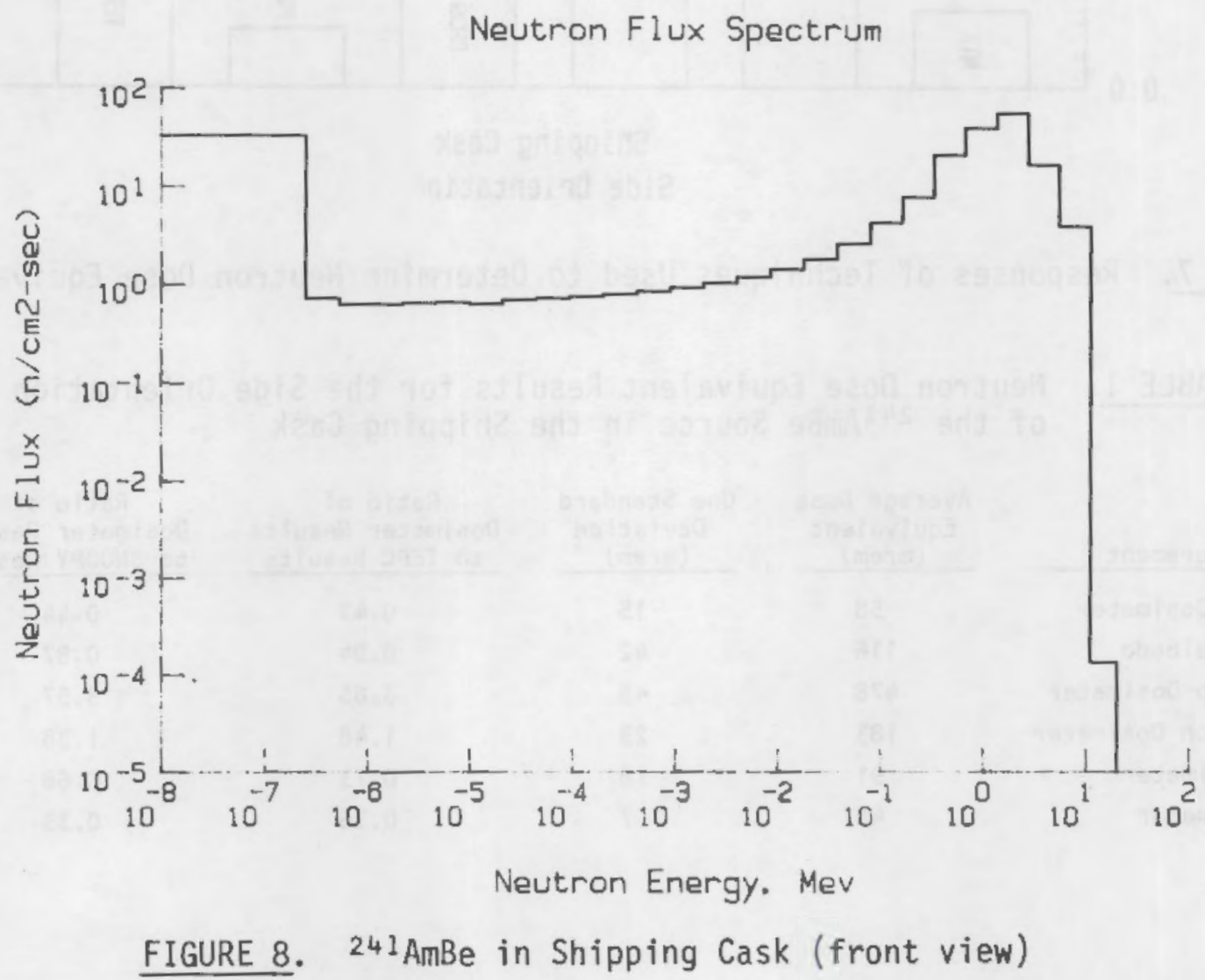




\section{Neutron Flux Spectrum}

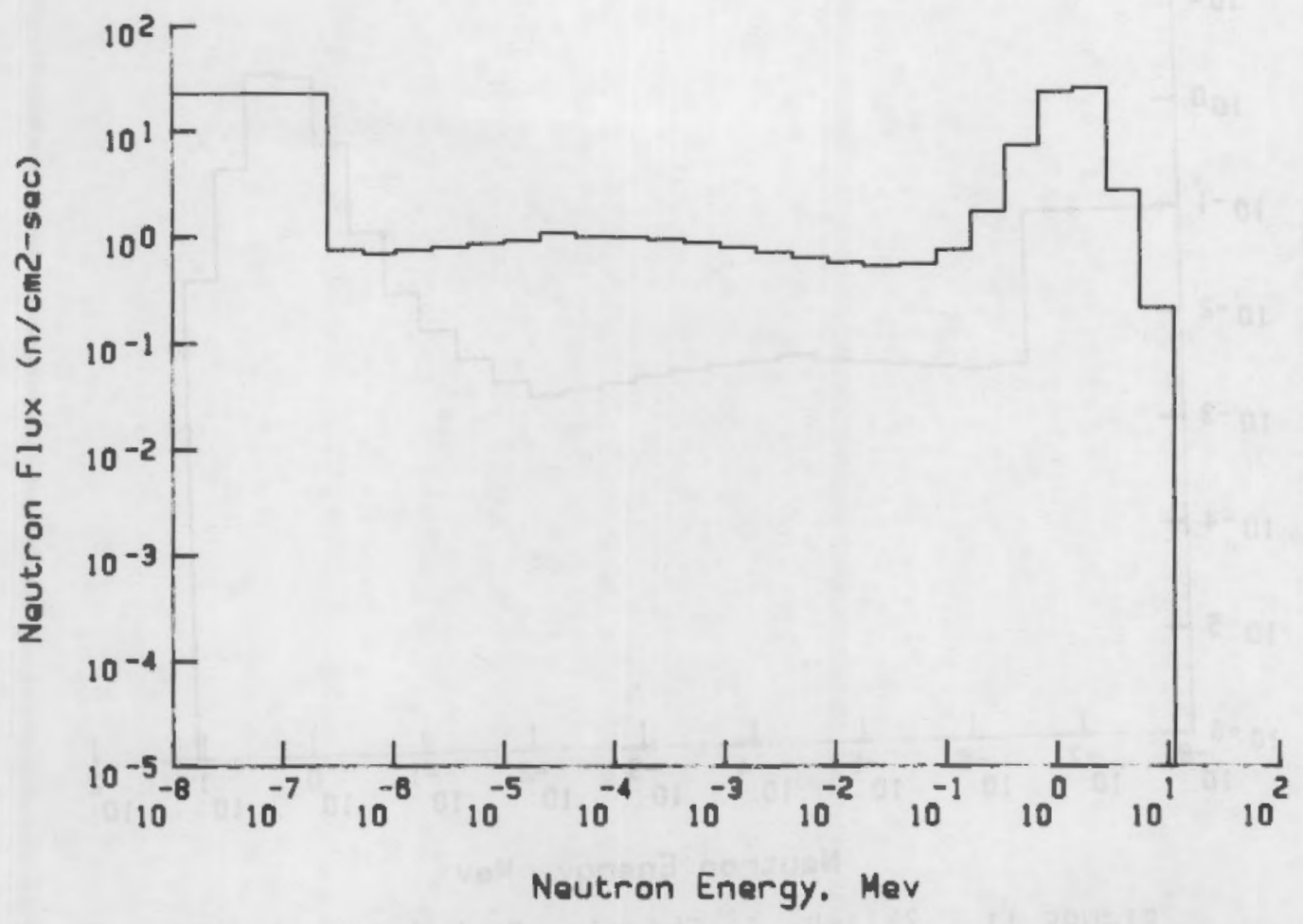

FIGURE 9. ${ }^{241} \mathrm{AmBe}$ in Shipping Cask (side view)

Dose Eq. Spectrum

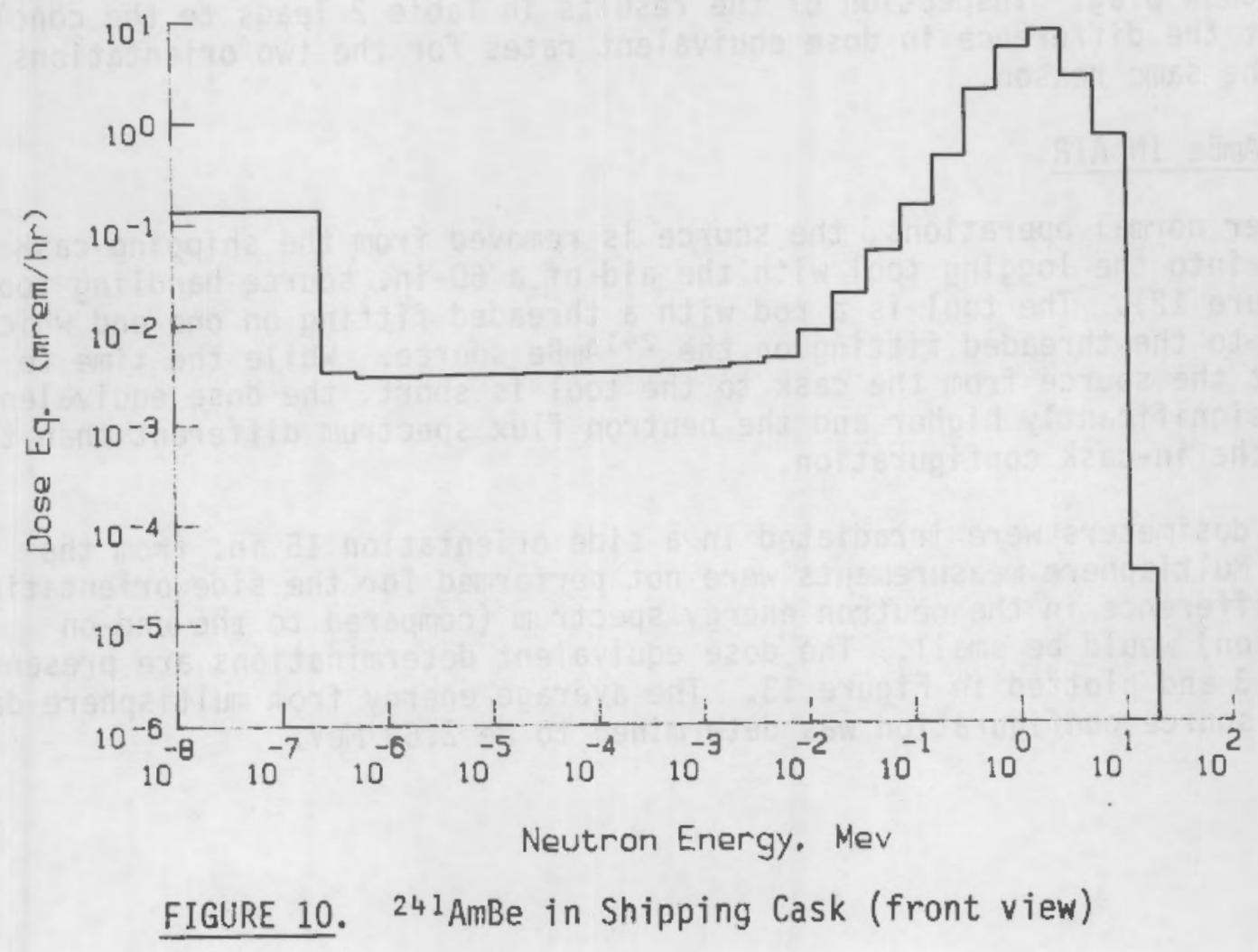


Dose Eq. Spectrum

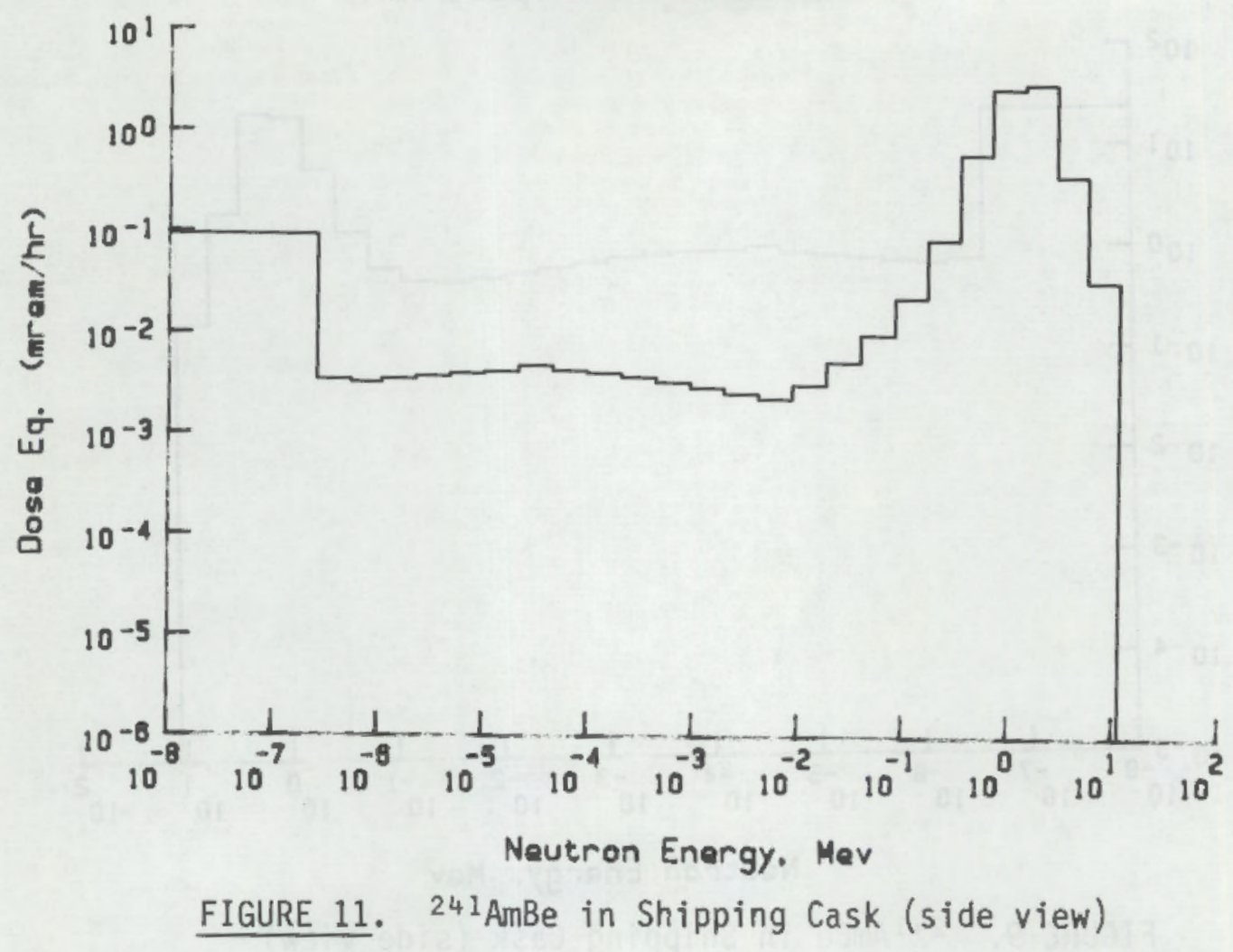

of the cask must traverse $8.25 \mathrm{in}$. of moderator while the neutrons emerging from the end of the cask must only traverse the end of the steel source holder and the cask plug. Inspection of the results in Table 2 leads to the conclusion that the difference in dose equivalent rates for the two orientations is due to the same reason.

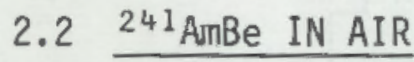

Under normal operations, the source is removed from the shipping cask and inserted into the logging tool with the aid of a $60-i n$. source handling tool (see Figure 12). The tool is a rod with a threaded fitting on one end which attaches to the threaded fitting on the ${ }^{241} \mathrm{AmBe}$ source. While the time to transport the source from the cask to the tool is short, the dose equivalent rate is significantly higher and the neutron flux spectrum different than the one for the in-cask configuration.

The dosimeters were irradiated in a side orientation $15 \mathrm{in}$. from the source. Multisphere measurements were not performed for the side orientation as the difference in the neutron energy spectrum (compared to the end-on orientation) would be small. The dose equivalent determinations are presented in Table 3 and plotted in Figure 13. The average energy from multisphere data for this source configuration was determined to be $2.69 \mathrm{MeV}$. 


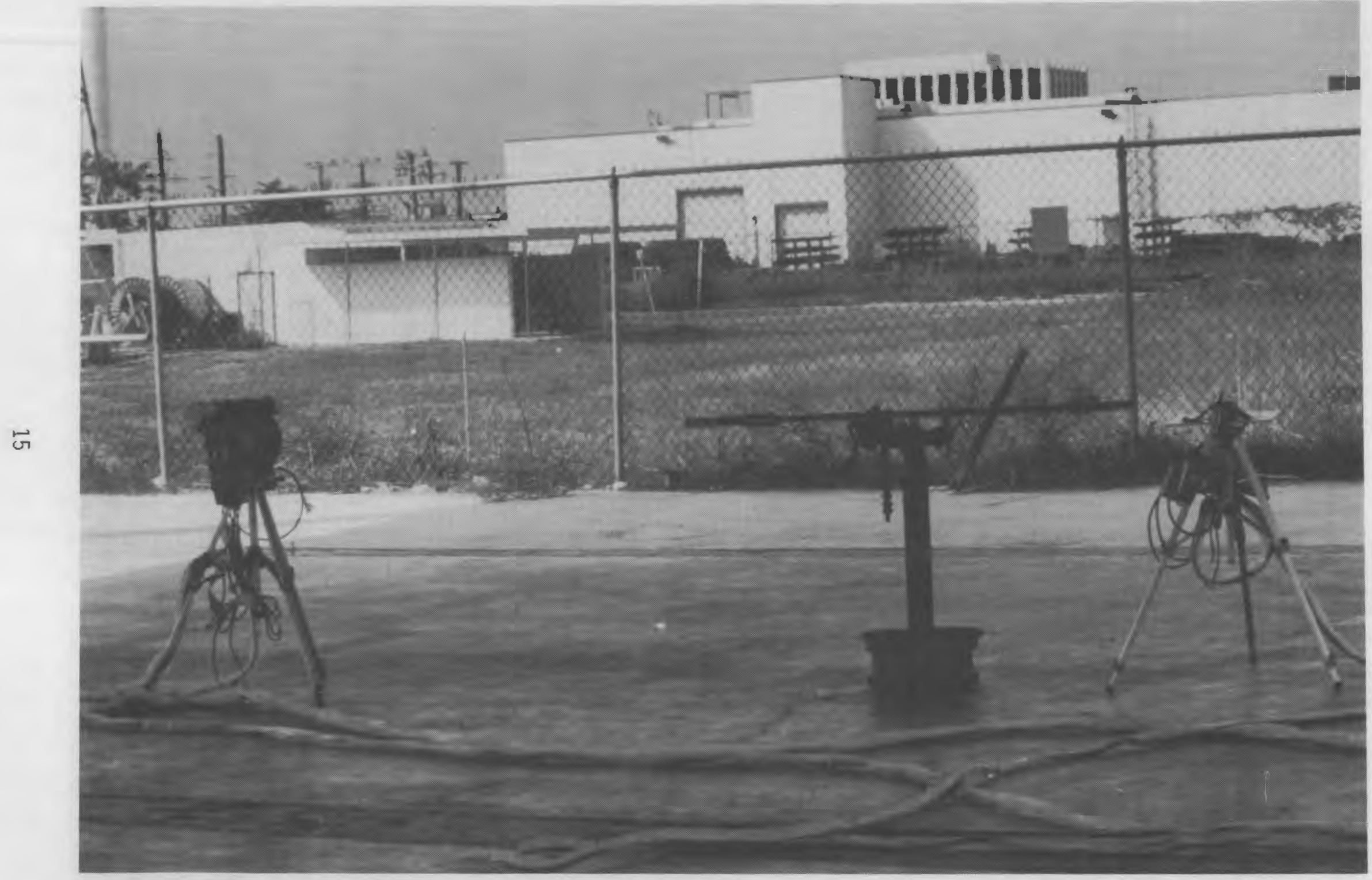

FIGURE 12. ${ }^{241}$ AmBe Source in Handling Tool 
TABLE 3. Neutron Dose Equivalent Results for the Side Orientation of the ${ }^{241} \mathrm{AmBe}$ Source in the Handling Tool

\begin{tabular}{|c|c|c|c|c|}
\hline Measurement & $\begin{array}{c}\text { Average Dose } \\
\text { Equivalent } \\
\text { (mrem) } \\
\end{array}$ & $\begin{array}{c}\text { One Standard } \\
\text { Deviation } \\
\text { (mrem) } \\
\end{array}$ & $\begin{array}{l}\text { Ratio of } \\
\text { Dosimeter Results } \\
\text { to TEPC Results } \\
\end{array}$ & $\begin{array}{l}\quad \text { Ratio of } \\
\text { Dosimeter Results } \\
\text { to SNOOPY Results } \\
\end{array}$ \\
\hline NTA Film Dosimeter & 4480 & 114 & 0.93 & 1.20 \\
\hline HMPD TLD-albedo & 2620 & 400 & 0.55 & 0.70 \\
\hline TLD-albedo Dosimeter & 5464 & 554 & 1.14 & 1.46 \\
\hline Combination Dosimeter & 3950 & 309 & 0.82 & 1.06 \\
\hline CR-39 Dosimeter & 3950 & 309 & 0.82 & 1.06 \\
\hline Poly Dosimeter & 5980 & 544 & 1.25 & 1.60 \\
\hline
\end{tabular}

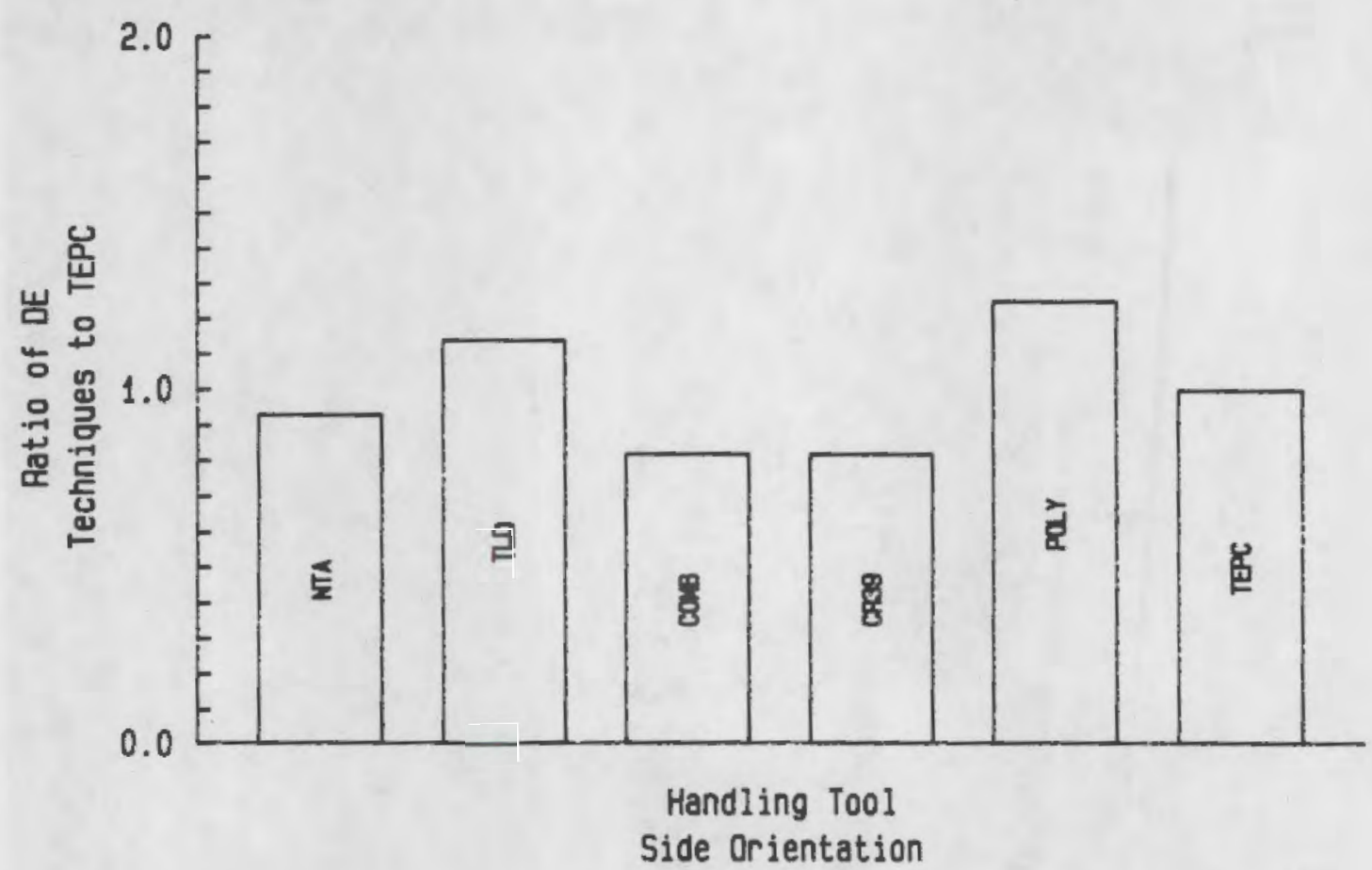

FIGURE 13. Responses of Techniques Used to Determine Neutron Dose Equivalent

The average neutron energy from multispheres was determined to be 2.69 MeV. That is lower than the published value of $4.5 \mathrm{MeV}$ average neutron energy (DePangher and Tochilin 1963). The difference is due to the lack of resolution of the multisphere analysis. The count rates from the seven detector configurations are used to generate a neutron energy spectrum from thermal to $20 \mathrm{MeV}$. The energy groupings of the fluence are logaritrmic (i.e. there are three energy groupings per decade), so the analysis inherently spreads the spectrum and resolution is lost. The spreading of the spectrum 
TABLE 4. Neutron Dose Equivalent Rates for the ${ }^{241} \mathrm{AmBe}$ Source in the Handling Tool

\begin{tabular}{|c|c|c|c|c|}
\hline Measurement & $\begin{array}{c}\text { Average Dose } \\
\text { Equivalent } \\
\text { Rate (mrem } / \mathrm{hr} \text { ) } \\
\end{array}$ & $\begin{array}{c}\begin{array}{c}\text { Average } \\
\text { Neutron Energy } \\
\text { (MeV) }\end{array} \\
\end{array}$ & $\begin{array}{l}\quad \text { Ratio of } \\
\text { Dose Equival ent } \\
\text { Measurement to } \\
\text { TEPC Results } \\
\end{array}$ & $\begin{array}{l}\quad \text { Ratio of } \\
\text { Dose Equivalent } \\
\text { Measurement to } \\
\text { SNOOPY Results } \\
\end{array}$ \\
\hline $\begin{array}{l}\text { Side Orientation } \\
\text { SNOOPY } \\
\text { TEPC }\end{array}$ & $\begin{array}{l}35 \\
45\end{array}$ & $\overline{-}$ & $\begin{array}{l}0.78 \\
1.00\end{array}$ & $\begin{array}{l}1.00 \\
1.29\end{array}$ \\
\hline $\begin{array}{l}\text { End-On Orientation } \\
\text { Multispheres } \\
\text { SNOOPY } \\
\text { RB10 } \\
\text { TEPC }\end{array}$ & $\begin{array}{l}11 \\
36 \\
13 \\
36\end{array}$ & $\begin{array}{l}2.69 \\
- \\
-\end{array}$ & $\begin{array}{l}0.31 \\
1.00 \\
0.36 \\
1.00\end{array}$ & $\begin{array}{l}0.31 \\
1.00 \\
0.36 \\
1.00\end{array}$ \\
\hline
\end{tabular}

has the effect of lowering the calculated average neutron energy. Dosimeters which use ${ }^{241} \mathrm{AmBe}$ as a calibration source, or use a calibration based on the dosimeter response at $4.5 \mathrm{MeV}$ should not be affected (a fact which is borne out by noticing the close agreement between the TLD-albedo supplied by the dosimeter processor and the TEPC measurement in Table 3). The difference in average energy is a characteristic of the multisphere analysis only. Neutron energy and dose equivalent spectra are plotted in Figures 14 and 15.

\section{Neutron Flux Spectrum}

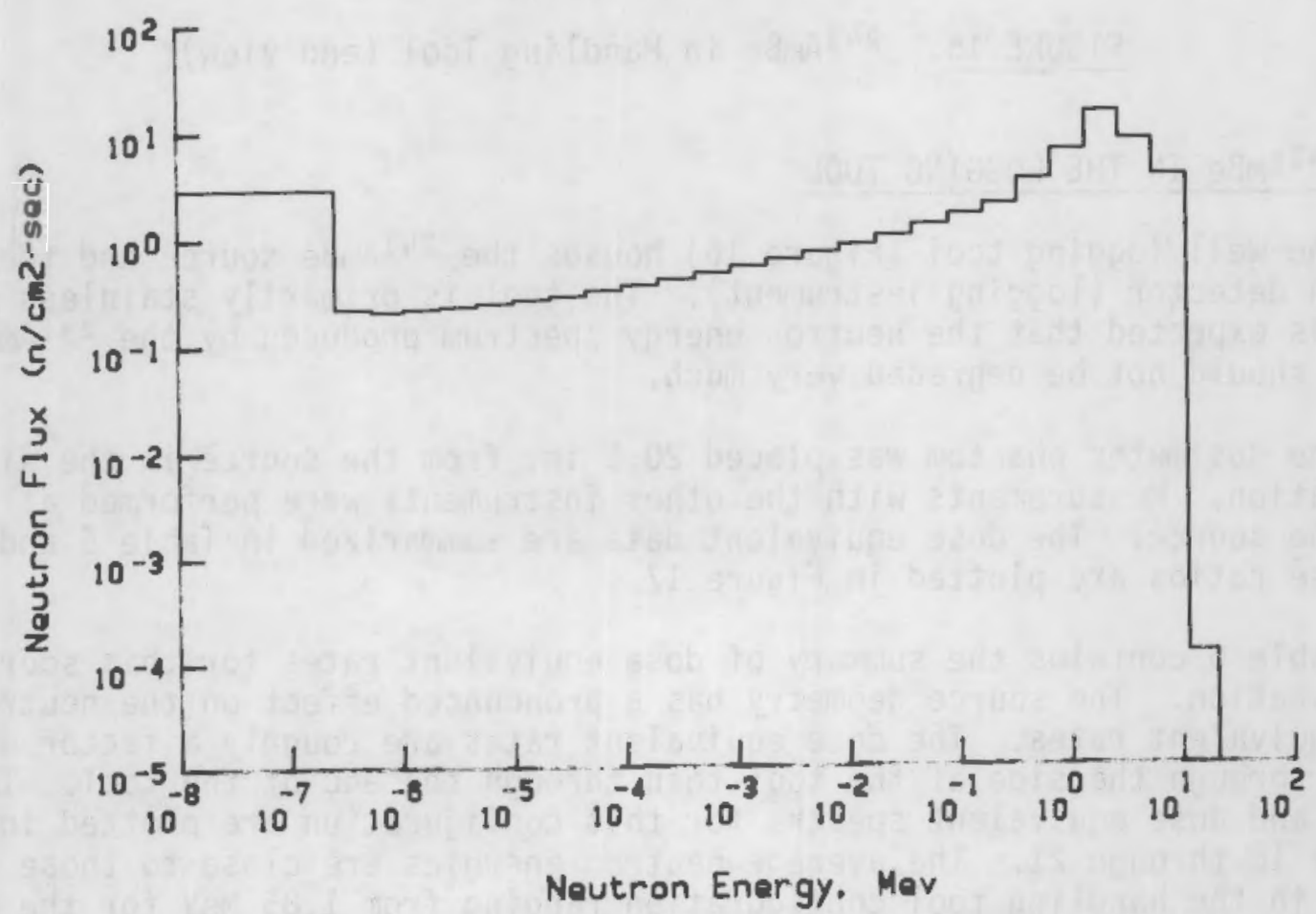

FIGURE 14. ${ }^{241} \mathrm{AmBe}$ in Handling Tool (end view) 
Dose Eq. Spectrum

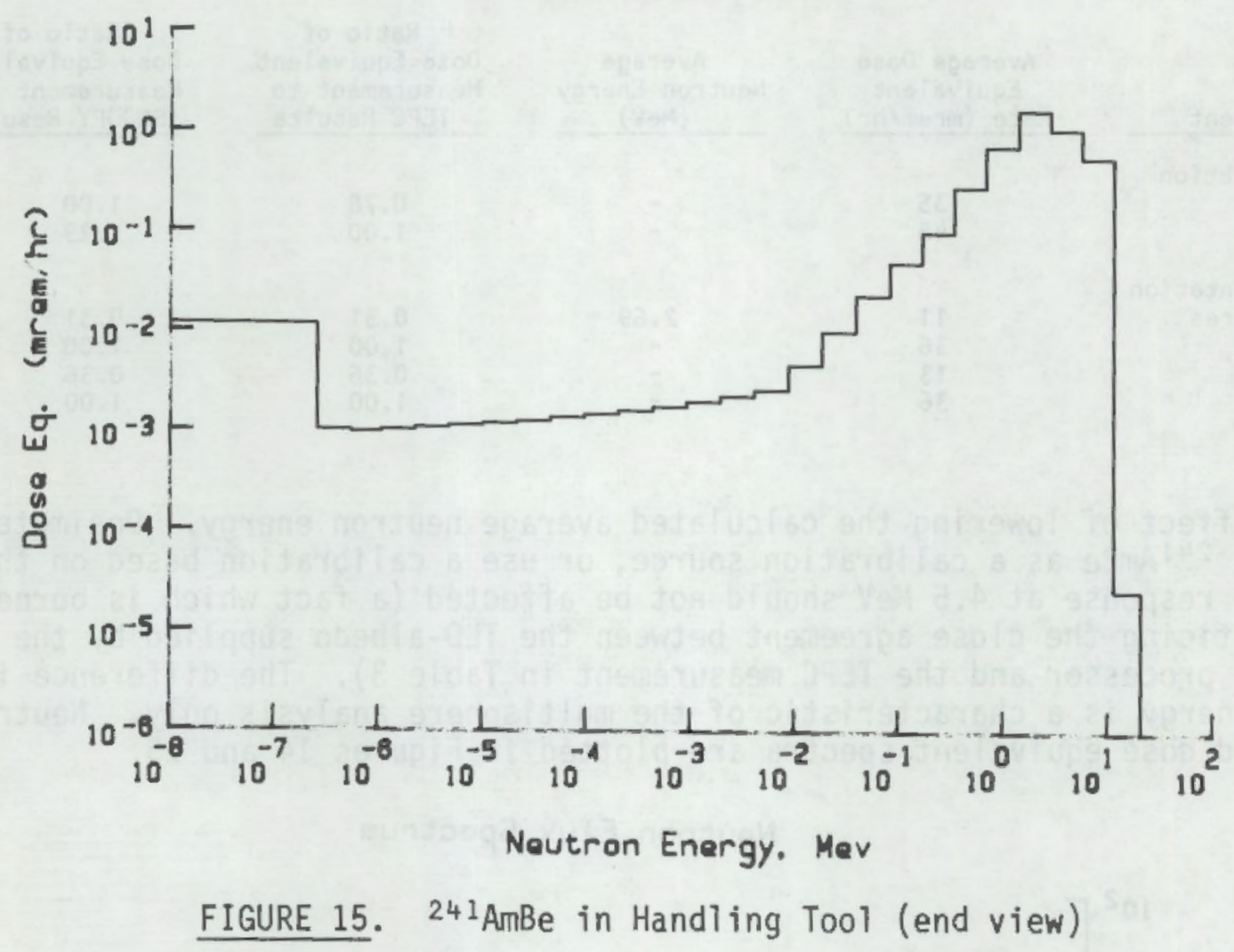

\section{$2.3 \quad{ }^{241} \mathrm{AmBe}$ IN THE LOGGING TOOL}

The well logging tool (Figure 16) houses the ${ }^{241} \mathrm{AmBe}$ source and the neutron detector (logging instrument). The tool is primarily stainless steel, so it is expected that the neutron energy spectrum produced by the ${ }^{241} \mathrm{AmBe}$ source should not be degraded very much.

The dosimeter phantom was placed $20.5 \mathrm{in}$. from the source in the side orientation. Measurements with the other instruments were performed at 24 in. from the source. The dose equivalent data are summarized in Table 5 and the response ratios are plotted in Figure 17.

Table 6 contains the summary of dose equivalent rates for this source configuration. The source geometry has a pronounced effect on the neutron dose equivalent rates. The dose equivalent rates are roughiy a factor of 7 higher through the side of the tool than through the end of the tool. The energy and dose equivalent spectra for this configuration are plotted in Figures 18 through 21. The average neutron energies are close to those of the source in the handling tool configuration ranging from $1.85 \mathrm{MeV}$ for the end-on orientation to $2.26 \mathrm{MeV}$ for the side orientation. 


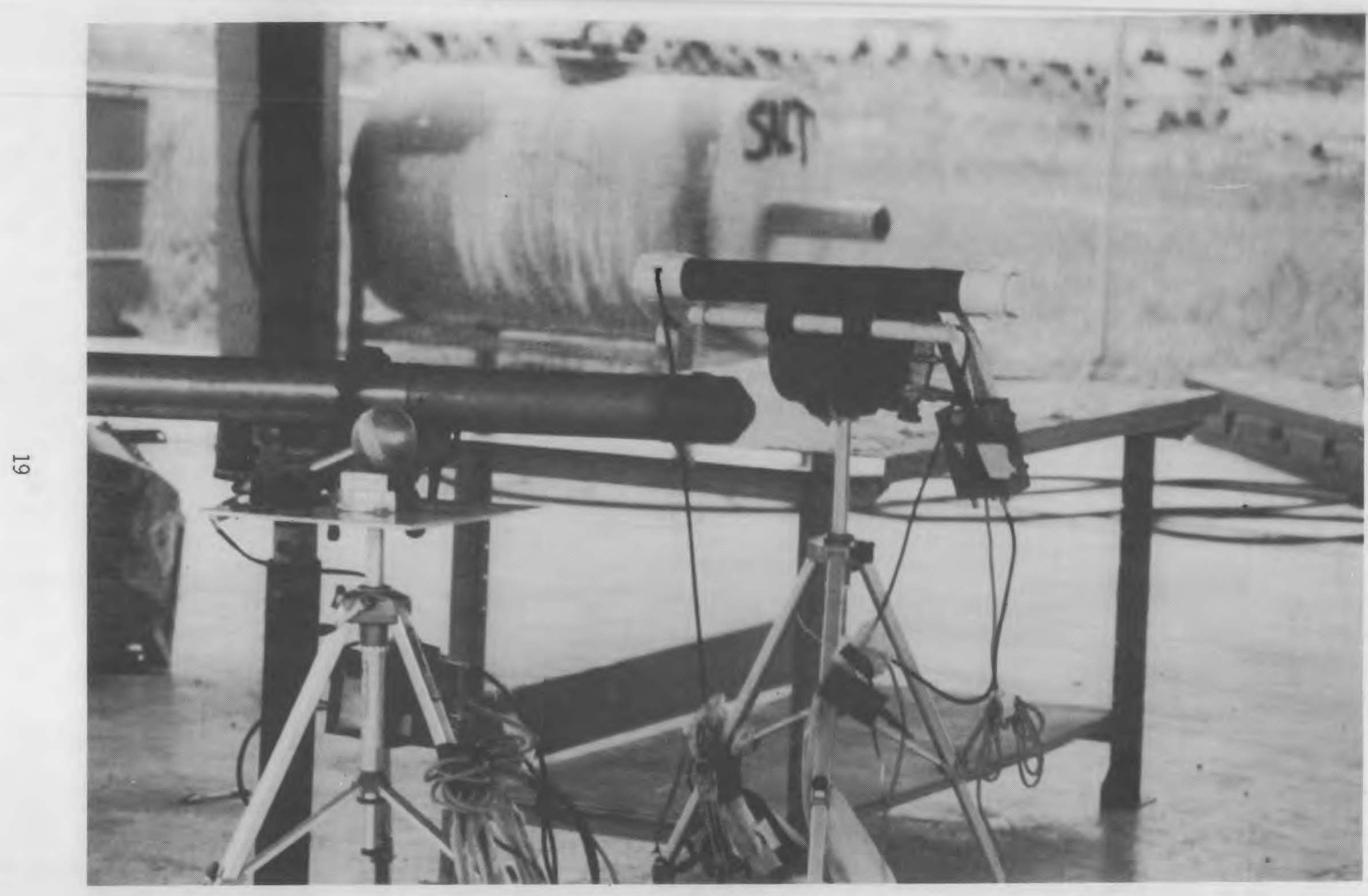

FIGURE 16. ${ }^{24} \mathrm{AmBe}$ Source in Logging Tool 
TABLE 5. Nritron Dose Equivalents for the Side Orientation it AmBe Source in the Logging Tool

\begin{tabular}{|c|c|c|c|c|}
\hline Measurement & $\begin{array}{c}\text { Average Dose } \\
\text { Equivai } t \\
\text { Rate (mrer } r \text { ) } \\
\end{array}$ & $\begin{array}{c}\text { Average } \\
\text { Neutron Energy } \\
(\mathrm{MeV}) \\
\end{array}$ & $\begin{array}{l}\text { Ratio of } \\
\text { Dosimeter Results } \\
\text { to TEPC ResuIts } \\
\end{array}$ & $\begin{array}{c}\text { Ratio of } \\
\text { Dosimeter Results } \\
\text { SNOOPY Results } \\
\end{array}$ \\
\hline NTA Fi1m Dusimeter & 92 & 110 & 0.56 & 0.61 \\
\hline HMPD TLD-a' du & 478 & 57 & 1.33 & 1.44 \\
\hline TLD-albedo Dosimeter & 1160 & 115 & 3.22 & 3.48 \\
\hline Combination Dos neter & 615 & 107 & 1.71 & 1.84 \\
\hline CR-39 Dosititer & 237 & 20 & 0.66 & 0.71 \\
\hline Poly Dosimeter & 280 & 42 & 0.78 & 0.84 \\
\hline
\end{tabular}

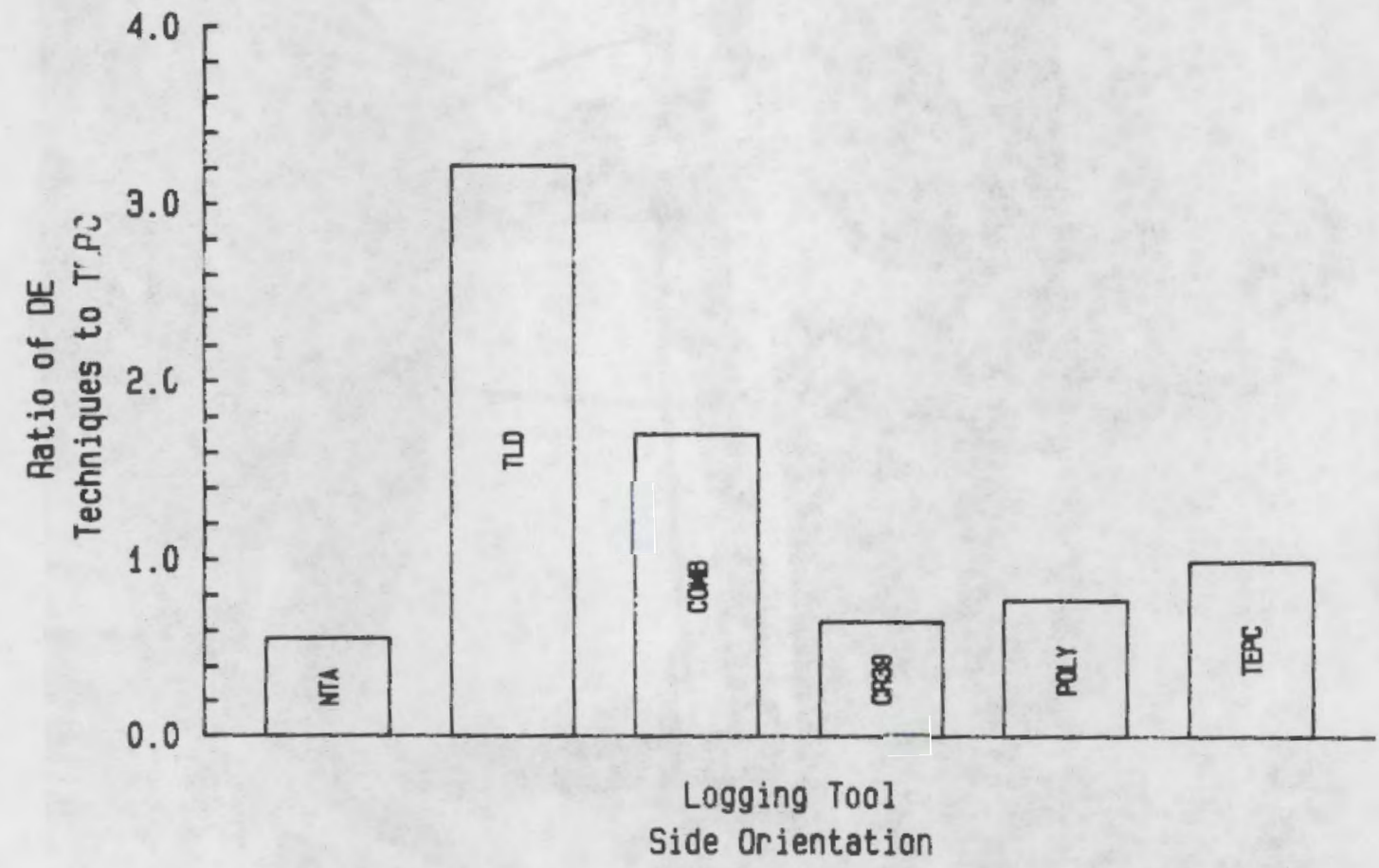

FIGURE 17. Responses of Techniques Used to Determine Neutron Dose Equivalent 


\section{TABLE 6. Neutron Dose Equivalent Rates for the ${ }^{241}$ AmBe Source in the Logging Tool}

\begin{tabular}{|c|c|c|c|c|}
\hline Measurement & $\begin{array}{c}\text { Average Dose } \\
\text { Equivalent } \\
\text { Rate (mrem/hr) } \\
\end{array}$ & $\begin{array}{c}\text { Average } \\
\text { Neutron Energy } \\
\text { (MeV) } \\
\end{array}$ & $\begin{array}{l}\text { Ratio of } \\
\text { Dose Equivalent } \\
\text { Measurement to } \\
\text { TEPC Results } \\
\end{array}$ & \begin{tabular}{l}
\multicolumn{1}{c}{ Ratio of } \\
Dose Equivalent \\
Measurement to \\
SNOOPY Results \\
\end{tabular} \\
\hline $\begin{array}{l}\text { Side Orientation } \\
\text { Multispheres } \\
\text { SNOOPY } \\
\text { RB10 } \\
\text { TEPC }\end{array}$ & $\begin{array}{l}62 \\
86 \\
76 \\
93\end{array}$ & $\begin{array}{l}2.26 \\
- \\
-\end{array}$ & $\begin{array}{l}0.67 \\
0.92 \\
0.82 \\
1.00\end{array}$ & $\begin{array}{l}0.72 \\
1.00 \\
0.88 \\
1.08\end{array}$ \\
\hline $\begin{array}{l}\text { End-On Orientation } \\
\text { Multispheres } \\
\text { SNOOPY } \\
\text { RB10 }\end{array}$ & $\begin{array}{r}9 \\
10 \\
10\end{array}$ & $\begin{array}{l}1.85 \\
- \\
-\end{array}$ & - & $\begin{array}{l}0.90 \\
1.00 \\
1.00\end{array}$ \\
\hline
\end{tabular}

\section{Neutron Flux Spectrum}

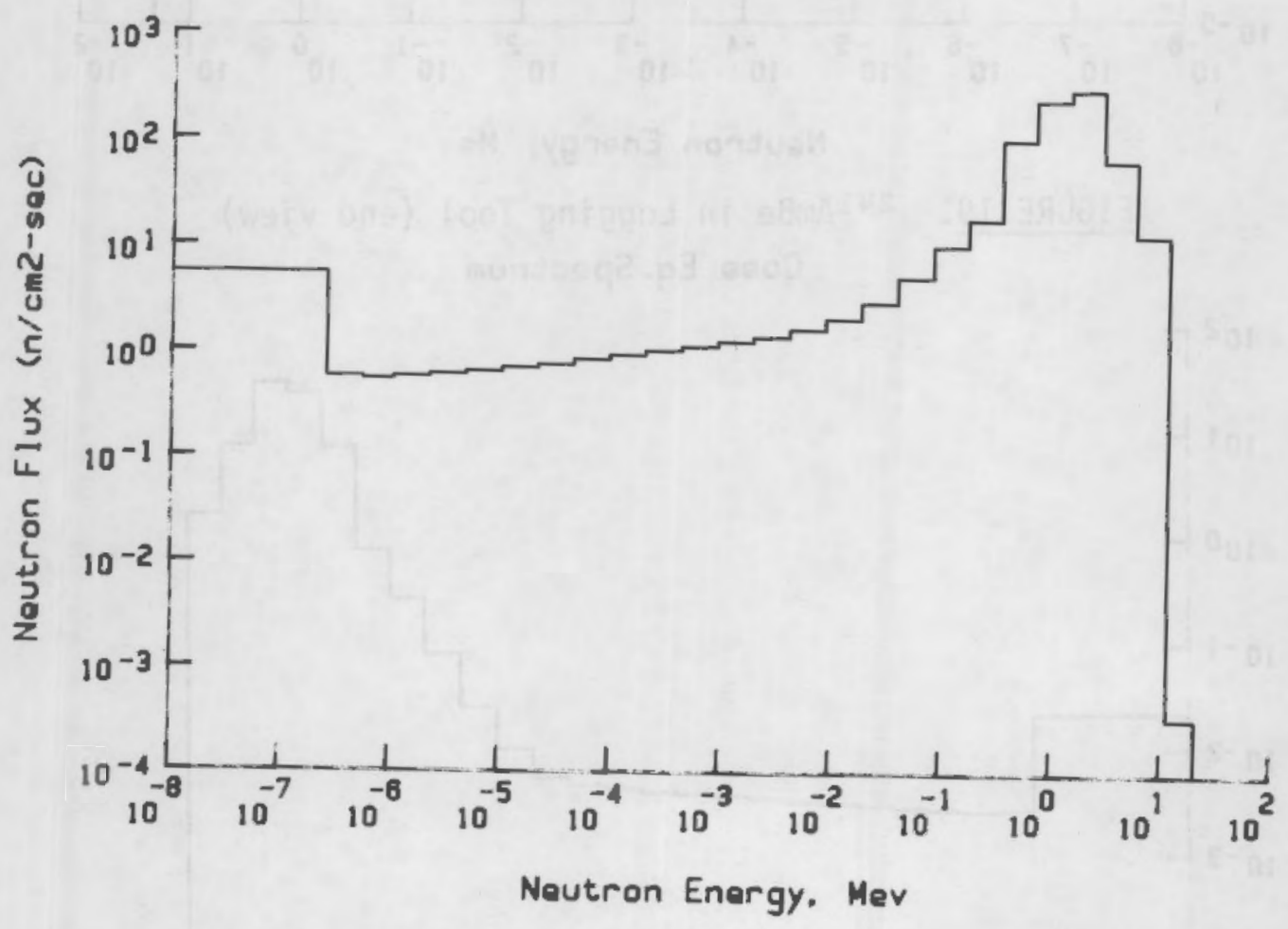

FIGURE 18. ${ }^{241} \mathrm{AmBe}$ in Logging Tool (side view) 


\section{Neutron Flux Spectrum}
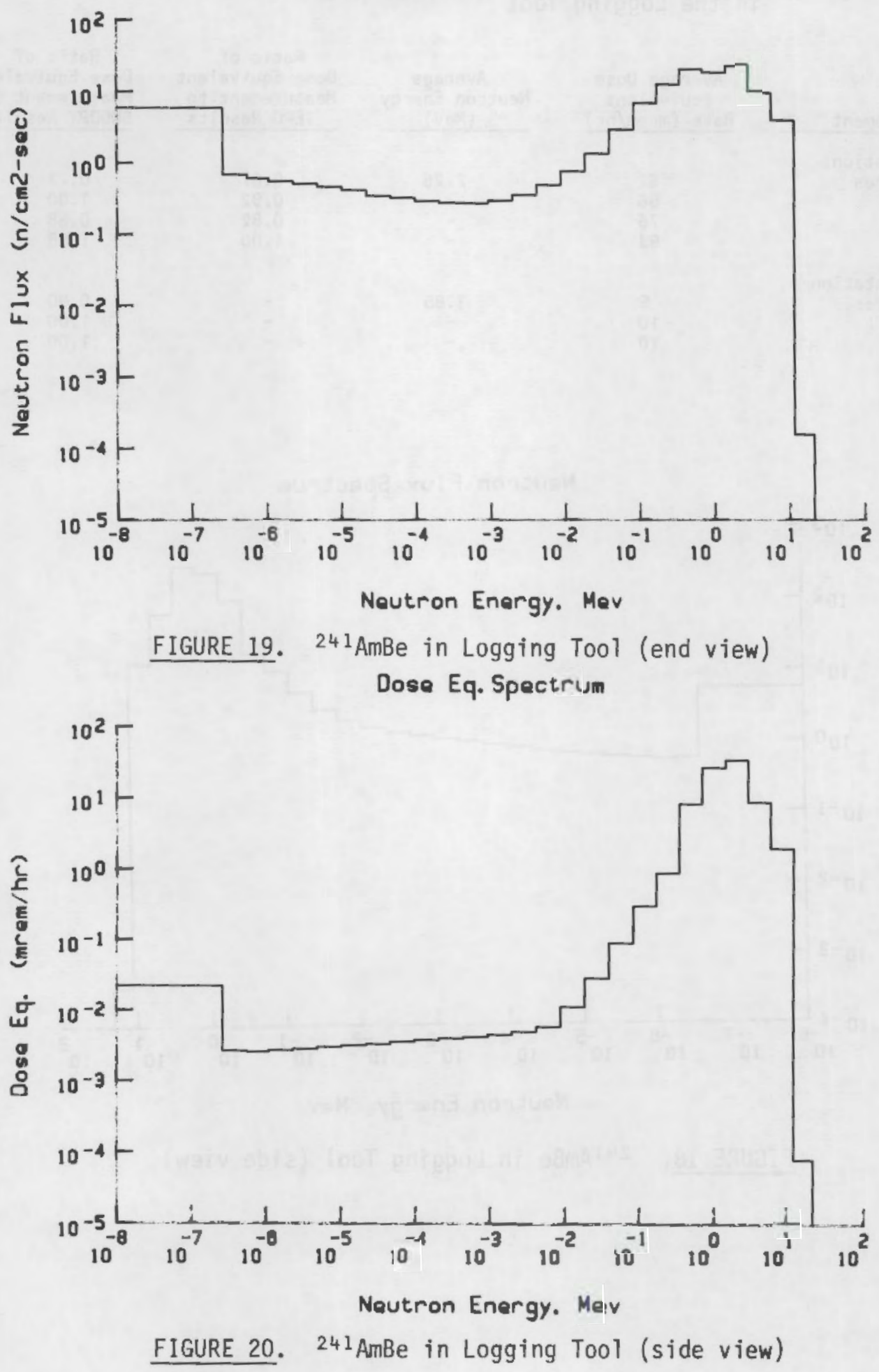
Dose Eq. Spectrum

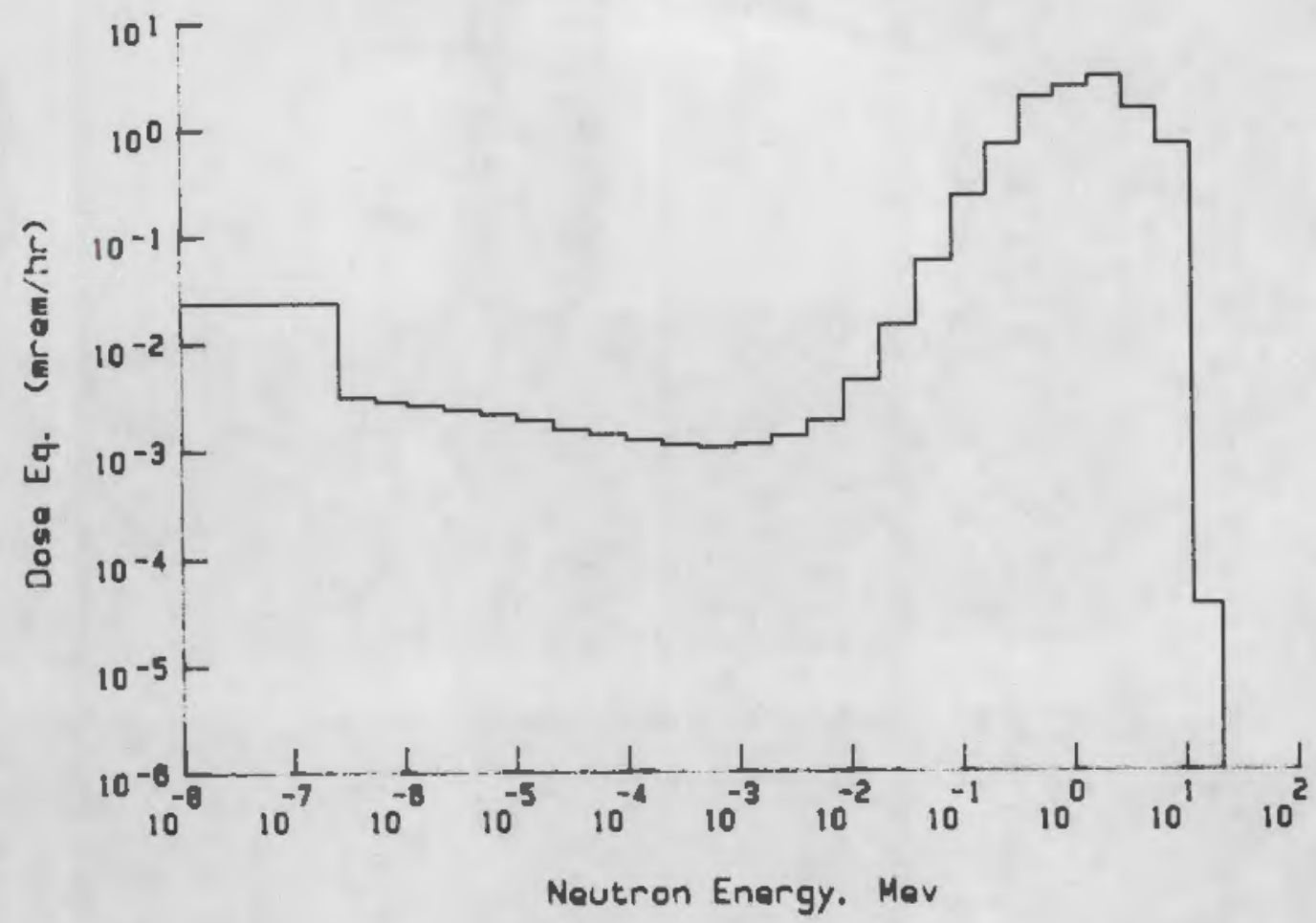

FIGURE 21. ${ }^{241} \mathrm{AmBe}$ in Logging Tool (end view)

\section{$2.42{ }^{241} \mathrm{AmBe}$ IN THE LOGGING TOOL CALIBRATOR SLEEVE}

A plastic sleeve is used to calibrate the internal neutron detector by providing moderator material with which to get a base reading. The tool is calibrated each time it is used in the field, producing a relatively moderated neutron energy spectrum as evidenced by the average neutron energies of 0.9 and $1.3 \mathrm{MeV}$. Figure 22 shows the configuration of the dosimeter irradiation. The center of the phantom face was placed $16 \mathrm{in}$. from the source which resides in the logging tool in the center of the calibrator sleeve. Dose equivalent results are presented in Table 7 and plotted in Figure 23. Only 1 NTA film dosimeter was irradiated for this source configuration.

The results of dosimeter data presented in Table 7 are indicative of a moderated neutron spectrum. The NTA and track etch dosimeters have decreased response ratios when compared to those ratios from the dosimeters irradiated under different source configurations. The decreased response ratio is due to the shift of neutron energies below the relative energy-cutoffs of the dosimeters (energy cutoffs: NTA = approximately $0.6 \mathrm{MeV}, \mathrm{CR}-39=$ approximately $0.1 \mathrm{MeV}$ and Poly = approximately $1.5 \mathrm{MeV}$ ). The energy cutoff for a dosimeter is the neutron energy below which the dosimeter cannot detect neutrons. The TLD-albedo response ratio, in contrast, is greater than for other source configurations, again indicative of a moderated neutron energy spectrum. 


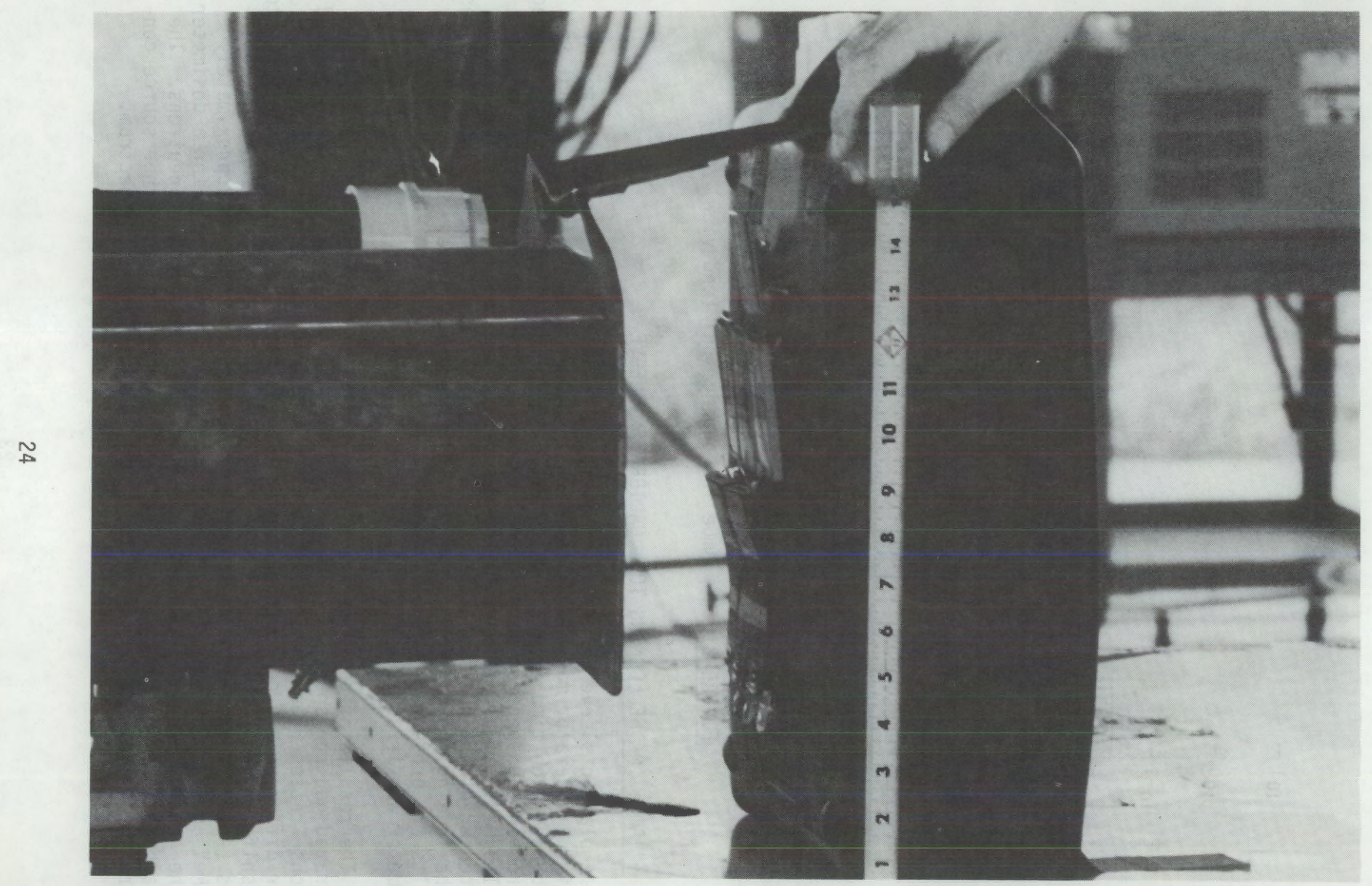

FIGURE 22. ${ }^{241} \mathrm{AmBe}$ in Plastic Calibrator Sleeve 


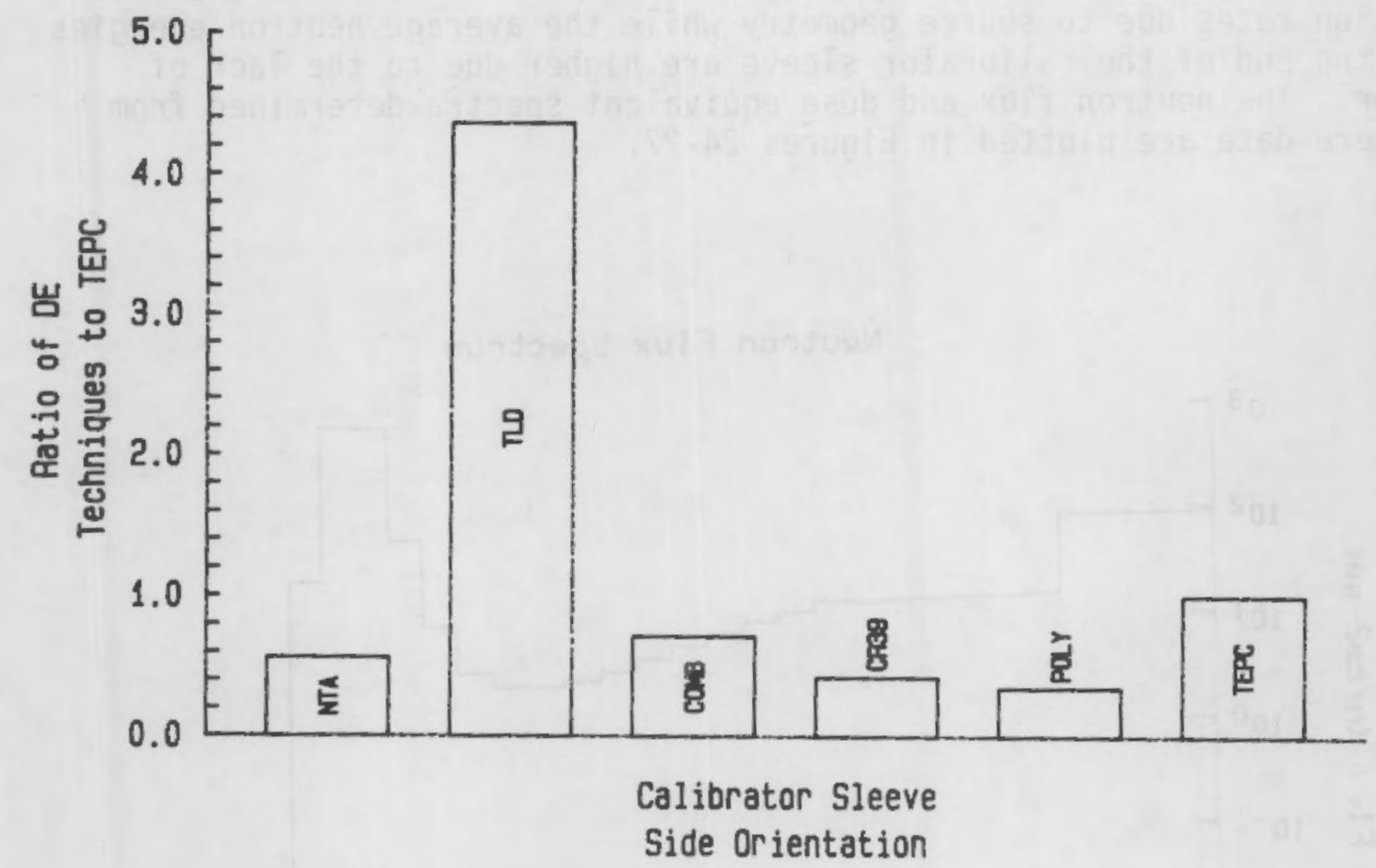

FIGURE 23. Responses of Techniques Used to Determine Neutron Dose Equivalent

TABLE 7. Neutron Dose Equivalent Results for the Side Orientation of the ${ }^{241}$ AmBe Source in the Logging Tool Calibrator Sleeve

\begin{tabular}{|c|c|c|c|c|}
\hline Measurement & $\begin{array}{c}\text { Average Dose } \\
\text { Equivalent } \\
\text { (mrem) } \\
\end{array}$ & $\begin{array}{c}\text { One Standard } \\
\text { Deviation } \\
\text { (mrem) } \\
\end{array}$ & $\begin{array}{l}\quad \text { Ratio of } \\
\text { Dosimeter Results } \\
\text { to TEPC Results } \\
\end{array}$ & $\begin{array}{l}\quad \text { Ratio of } \\
\text { Dosimeter Results } \\
\text { to SNOOPY Results }\end{array}$ \\
\hline NTA Film Dosimeter & 675 & - & 0.56 & 0.48 \\
\hline HMPD TLD-albedo & 2540 & 256 & 2.12 & 1.78 \\
\hline TLD-albedo Dosimeter & 5235 & 833 & 4.36 & 3.68 \\
\hline Combination Dosimeter & 847 & 27 & 0.71 & 0.60 \\
\hline CR-39 Dosimeter & 500 & 7 & 0.42 & 0.35 \\
\hline Poly Dosimeter & 420 & 0 & 0.35 & 0.30 \\
\hline
\end{tabular}


The dose equivalent rate results are summarized in Table 7 . The measurements performed in the sid orientation were performed $16 \mathrm{in}$. from the source while the TEPC and SNOOPY, asurements in the end-on orientation were at 16 in. and the multisphere measurement was at $18 \mathrm{in}$. from the source. As mentioned before, the end-on dose equivalent rates are smaller than the side orientation rates due to source geometry while the average neutron energies through the end of the calibrator sleeve are higher due to the lack of moderator. The neutron flux and dose equivalent spectra determined from multisphere data are plotted in Figures 24-27.

Neutron Flux Spectrum

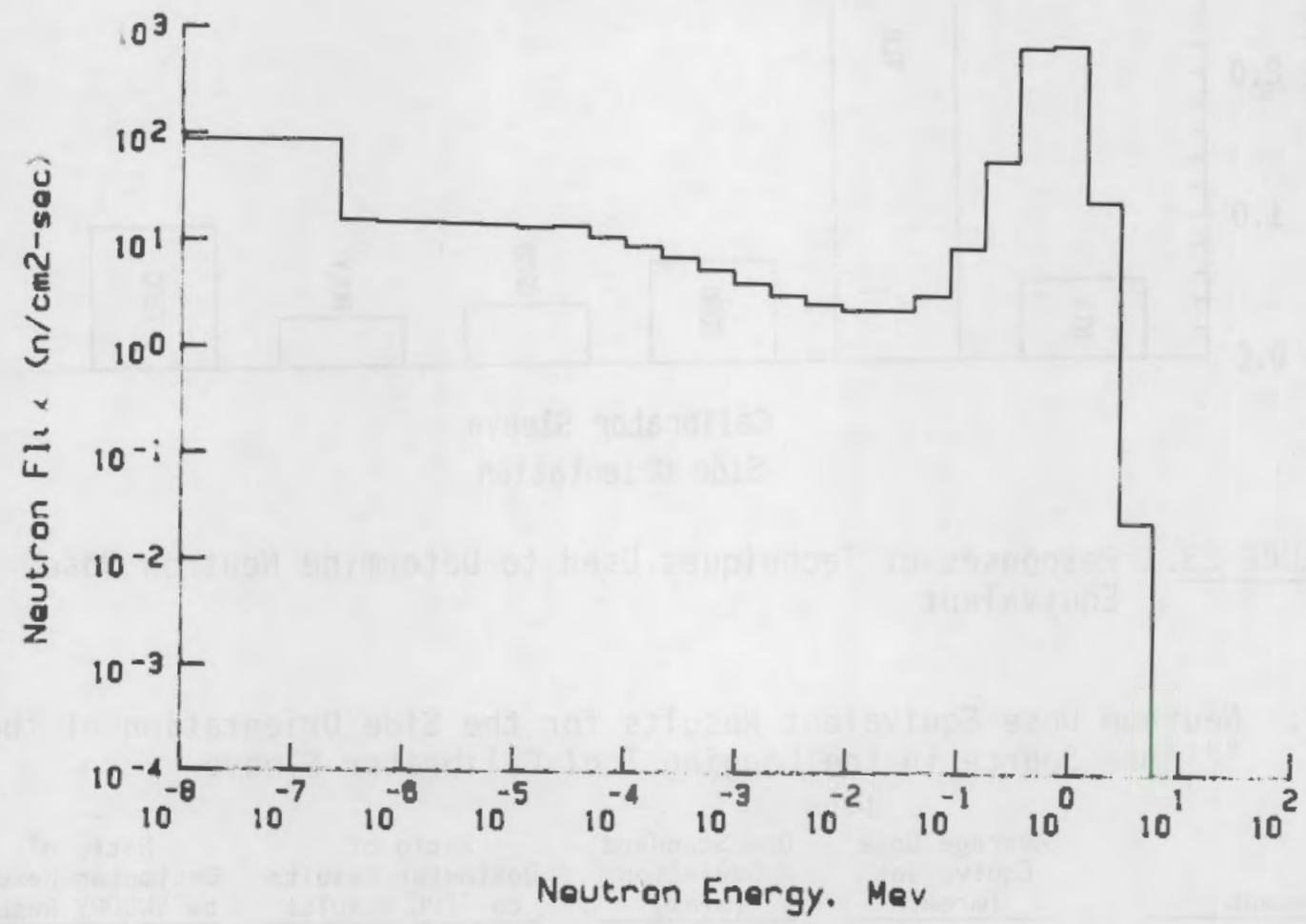

FIGURE 24. ${ }^{241} \mathrm{AmBe}$ in Logging Tool Calibrator Sleeve (side view) 


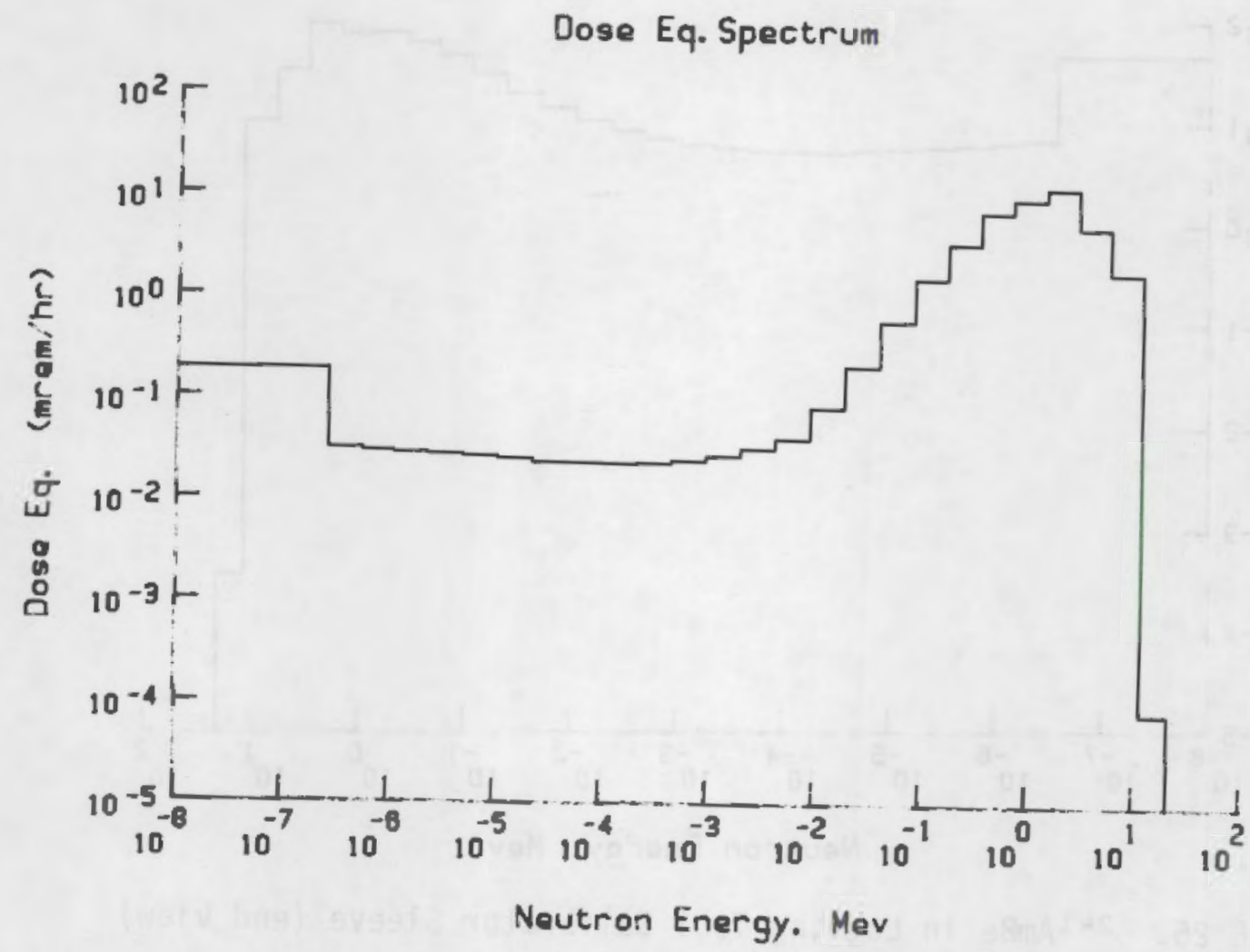

FIGURE 27. ${ }^{241} \mathrm{AmBe}$ in Logging Tool Calibrator Sleeve (end view)

TABLE 8. Neutron Dose Equivalent Rates for the ${ }^{241}$ AmBe Source in the Logging Tool Calibrator Sleeve

\begin{tabular}{|c|c|c|c|c|}
\hline Measurement & $\begin{array}{c}\text { Average Dose } \\
\text { Equivalent } \\
\text { Rate (mrem/hr) } \\
\end{array}$ & $\begin{array}{c}\text { Average } \\
\text { Neutron Energy } \\
\text { (MeV) } \\
\end{array}$ & $\begin{array}{l}\text { Ratio of Dose } \\
\text { Equivalent Rate } \\
\text { Measurement to } \\
\text { TEPC Results } \\
\end{array}$ & $\begin{array}{l}\text { Ratio of Dose } \\
\text { Equivalent Rate } \\
\text { Measurement to } \\
\text { SNOOPY Results } \\
\end{array}$ \\
\hline $\begin{array}{l}\text { Side Orientation } \\
\text { Multispheres } \\
\text { SNOOPY } \\
\text { RB10 } \\
\text { TEPC }\end{array}$ & $\begin{array}{l}26 \\
45 \\
33 \\
38\end{array}$ & $\begin{array}{l}0.89 \\
\vdots \\
-\end{array}$ & $\begin{array}{l}0.68 \\
1.18 \\
0.87 \\
1.00\end{array}$ & $\begin{array}{l}0.58 \\
1.00 \\
0.73 \\
0.80\end{array}$ \\
\hline $\begin{array}{l}\text { End-On Orientation } \\
\text { Mu1tispheres } \\
\text { SNOOPY } \\
\text { RB10 } \\
\text { TEPC }\end{array}$ & $\begin{array}{r}9 \\
8 \\
10 \\
11\end{array}$ & $\begin{array}{l}1.26 \\
\vdots \\
-\end{array}$ & $\begin{array}{l}0.82 \\
0.73 \\
0.91 \\
1.00\end{array}$ & $\begin{array}{l}1.13 \\
1.00 \\
1.25 \\
1.38\end{array}$ \\
\hline
\end{tabular}




\section{Neutron Flux Spectrum}

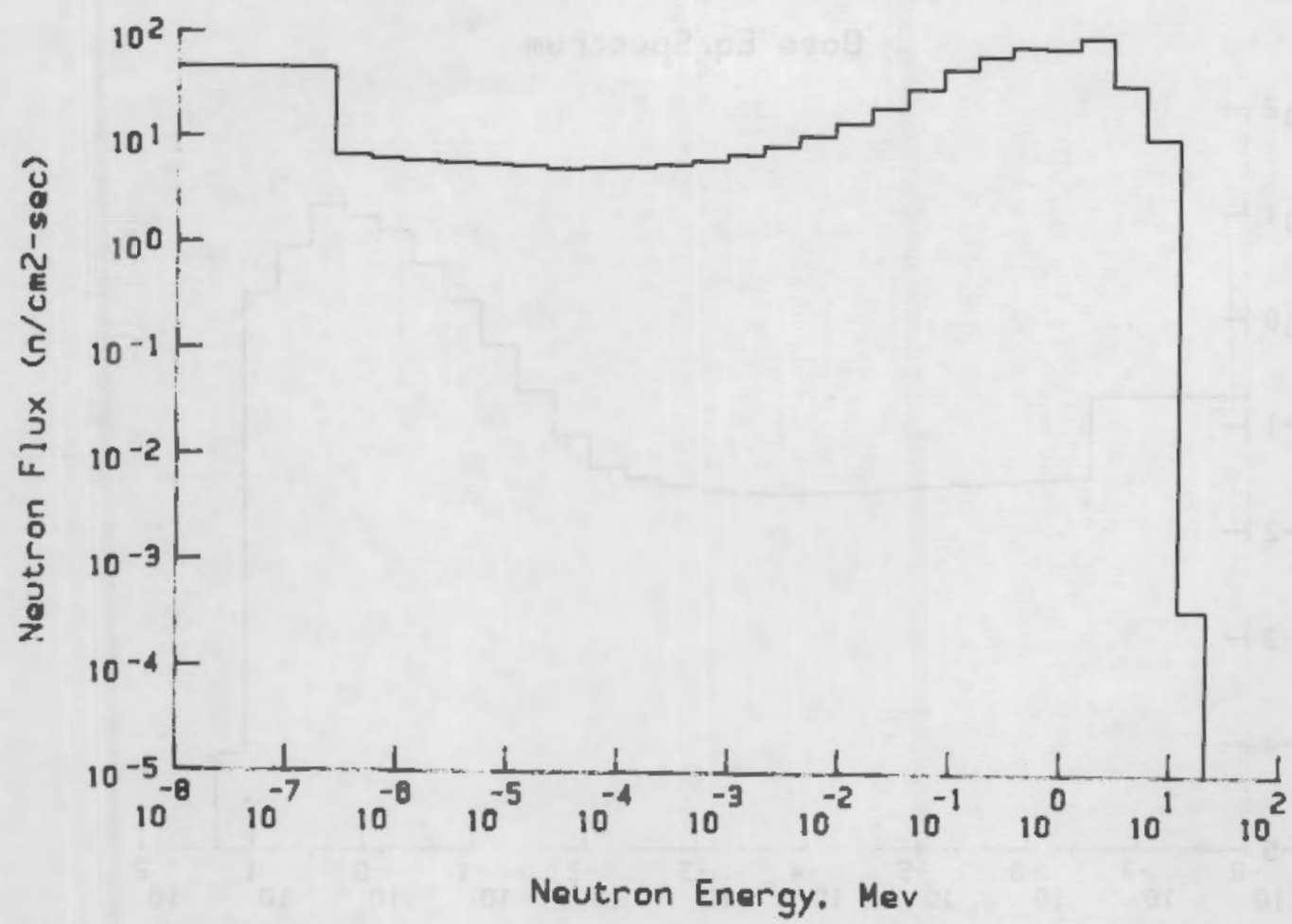

FIGURE 25. ${ }^{241} \mathrm{AmBe}$ in Logging Tool Calibrator Sleeve (end view) Dose Eq. Spectrum

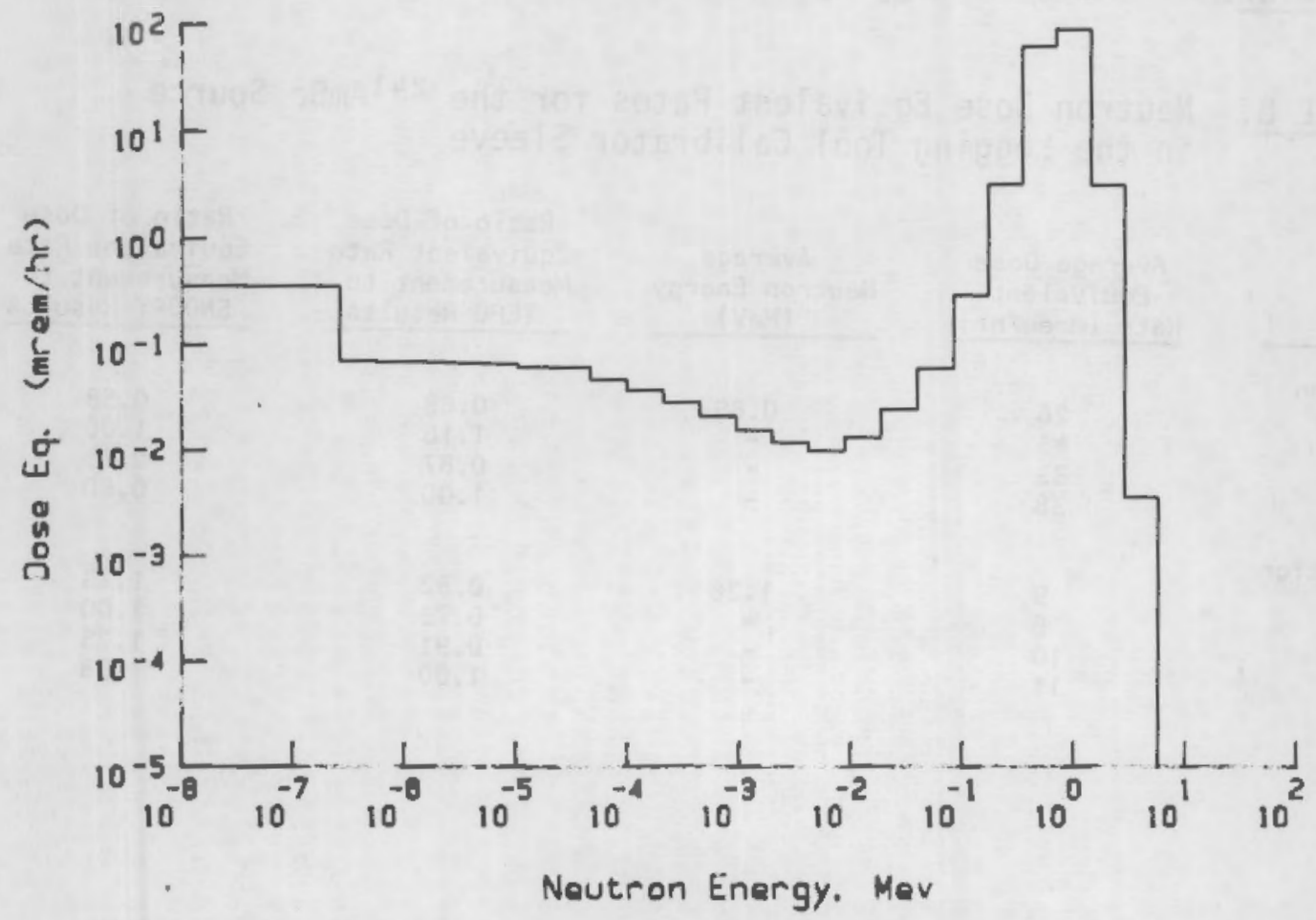

FIGURE 26. 241 AmBe in Logging Tool Calibrator Sleeve (side view) 


\subsection{NEUTRON GENERATOR IN THE SAND/WATER CALIBRATION TANK}

The logging tool which houses the neutron generator is inserted into several types of calibration tanks. The one which was measured during this study was the sand/water mixture calibration tank. The tank is a cylinder, roughly $4 \mathrm{ft}$ in length and $30 \mathrm{in}$. in diameter, as shown in Figure 28 . The SNOOPY was positioned on the top of the tank throughout the measurements. The dose equivalent rate reading from the SNOOPY was constant at $100 \mathrm{mrem} / \mathrm{hr}$. Table 9 contains the dose equivalent results for the measurement and Figure 29 is the plot of the response ratios. The response ratio of the TLD-albedo, 6.55 , shown in Table 9, is indicative of a neutron source with a neutron energy spectrum which is predominantly lower than the neutron energy spectrum of the calibration source (i.e. the response of the TLD-albedo decreases for increasing neutron energies). The response ratio of the polycarbonate dosimeter is larger than unity indicative of a neutron source with a neutron energy spectrum which is predominantly higher than that of the calibration source. For this irradiation geometry, both situations may be ture, i.e., the TLDalbedo is responding mainly to the neutrons which have been moderated in the sand/water tank, while the polycarbonate dosimeter is responding mainly to the higher energy neutrons which exit the tank uncollided. This situation illustrates the complexity of neutron dosimetry and the need for a dosimeter and calibration source which may be used together for an accurate determination of neutron dose equivalent.

Table 10 contains the dose equivalent rate results. The average neutron energies are very nearly the same for the two orientations and both neutron flux spectra indicate a predominance of high energy neutrons (Figures 30 and 32). Most of the neutron dose equivalent is contributed mainly by the higher energy neutron groups as indicated in Figures 31 and 33.

TABLE 9. Neutron Dose Equivalents for the Side Orientation of the Neutron Generator in the Sand/Water Calibration Tank

\begin{tabular}{|c|c|c|c|c|}
\hline Measurement & $\begin{array}{c}\text { Average Dose } \\
\text { Equivalent } \\
\text { (mrem) } \\
\end{array}$ & $\begin{array}{c}\text { One Standard } \\
\text { Deviation } \\
\text { (mrem) } \\
\end{array}$ & $\begin{array}{l}\text { Ratio of } \\
\text { Dosimeter Results } \\
\text { to TEPC Results } \\
\end{array}$ & $\begin{array}{l}\quad \text { Ratio of } \\
\text { Dosimeter Results } \\
\text { to SNOOPY Results } \\
\end{array}$ \\
\hline HMPD TLD-albedo & 90 & 144 & 0.35 & 0.63 \\
\hline TLD-albedo Dosimeter & 1703 & 161 & 6.55 & 11.79 \\
\hline Combination Dosimeter & 530 & 300 & 2.04 & 3.68 \\
\hline CR-39 Dosimeter & 150 & 54 & 0.58 & 1.04 \\
\hline Poly Dosimeter & 280 & 57 & 1.08 & 1.94 \\
\hline
\end{tabular}




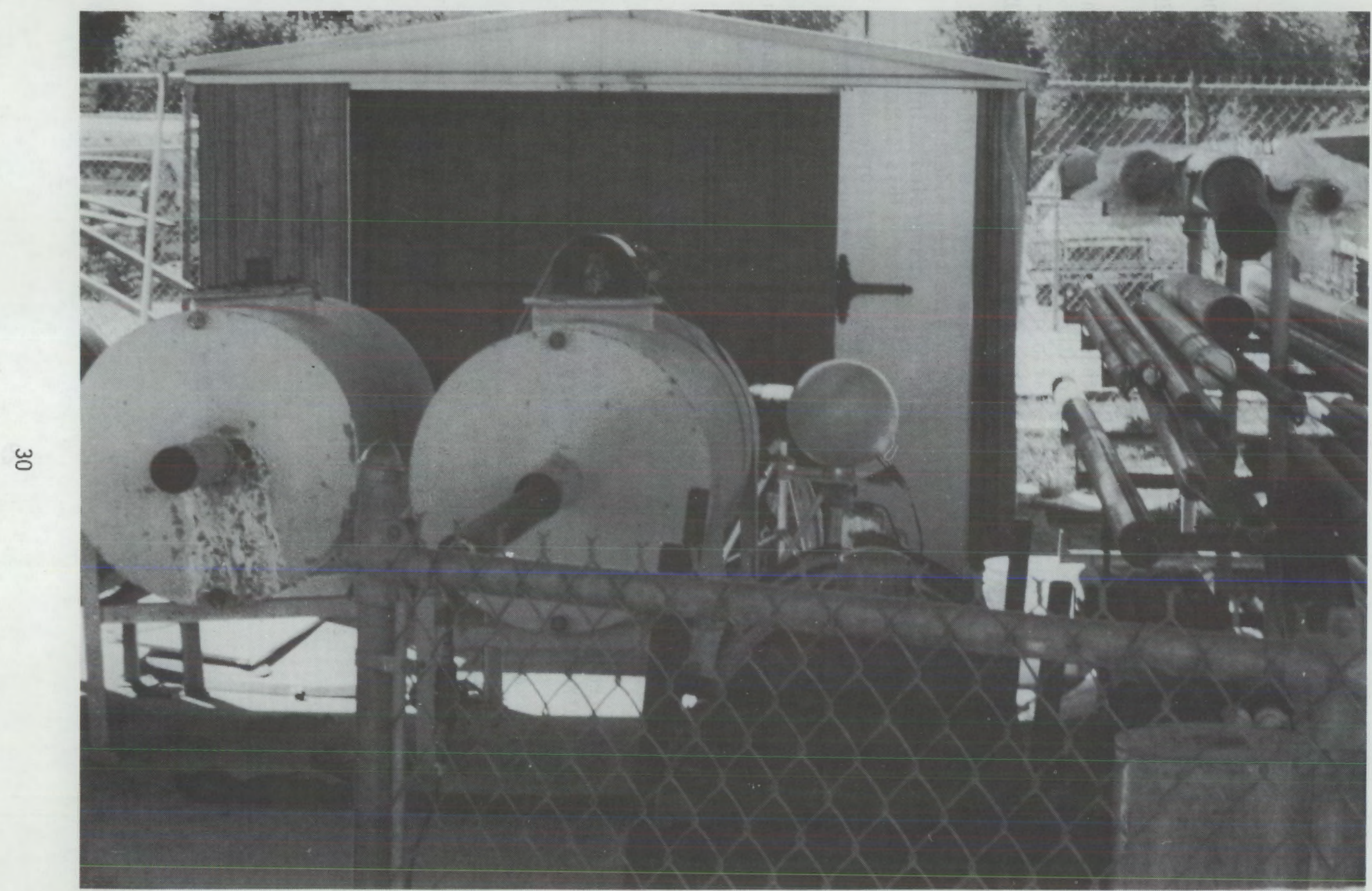

FIGURE 28. Neutron Generator in Sand/Water Calibration Tank 


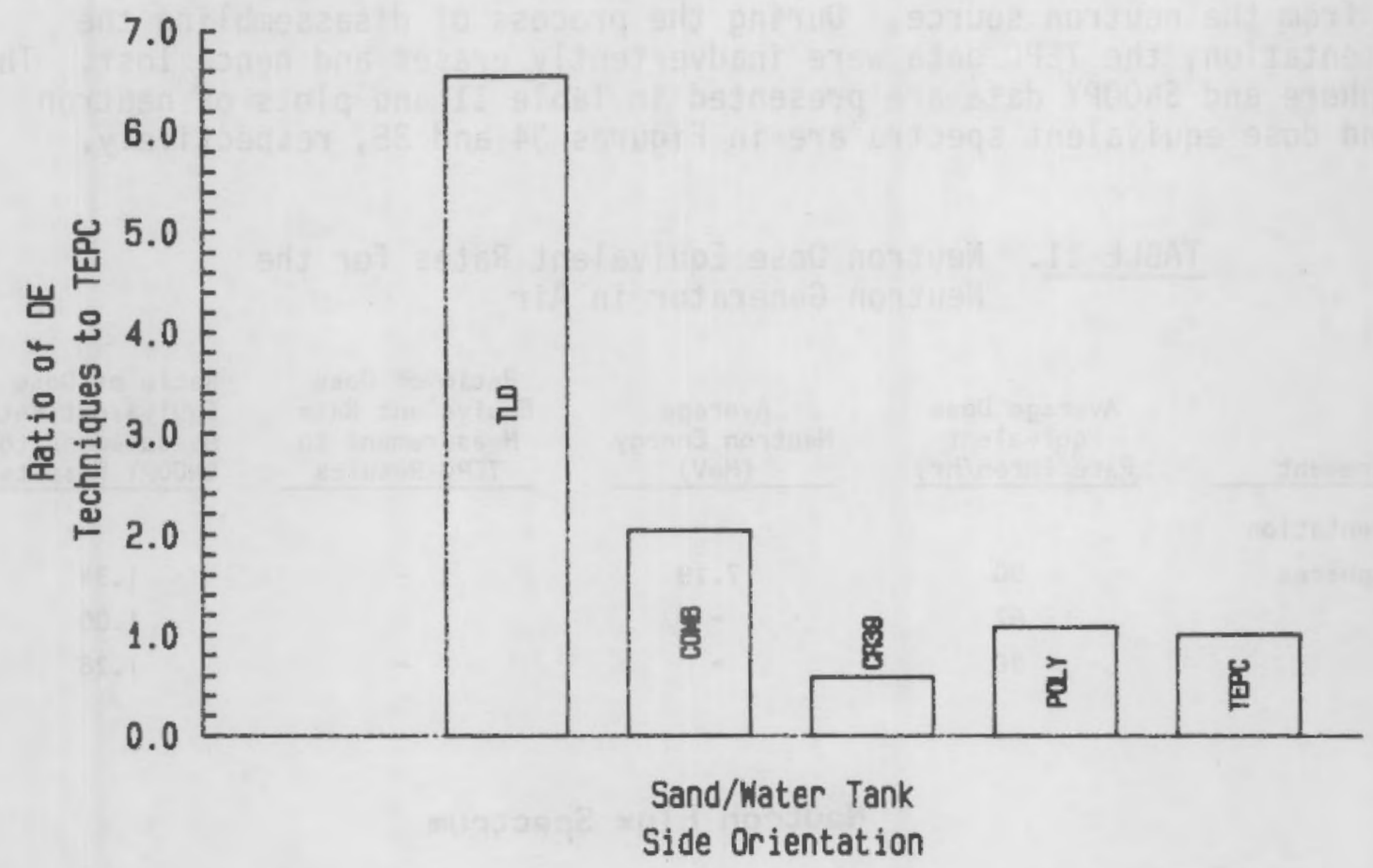

FIGURE 29. Responses of Techniques Used to Determine Neutron Dose Equivalent

TABLE 10. Neutron Dose Equivalent Rates for the Neutron Generator in the Sand/Water Calibration Tank

\begin{tabular}{|c|c|c|c|c|}
\hline Masurement & $\begin{array}{c}\text { Average Dose } \\
\text { Equivalent } \\
\text { Rate (mrem/hr) } \\
\end{array}$ & $\begin{array}{c}\text { Average } \\
\text { Neutron Energy } \\
\text { (MeV) } \\
\end{array}$ & $\begin{array}{l}\text { Ratio of Dose } \\
\text { Equivalent Rate } \\
\text { Measurement to } \\
\text { TEPC Results } \\
\end{array}$ & $\begin{array}{l}\text { Ratio of Dose } \\
\text { Equivalent Rate } \\
\text { Measurement to } \\
\text { SNOOPY Results } \\
\end{array}$ \\
\hline $\begin{array}{l}\text { Side Orientation } \\
\text { Multispheres } \\
\text { SNOOPY } \\
\text { RB10 } \\
\text { TEPC }\end{array}$ & $\begin{array}{l}18 \\
15 \\
21 \\
27\end{array}$ & $\begin{array}{l}1.89 \\
- \\
-\end{array}$ & $\begin{array}{l}0.67 \\
0.56 \\
0.78 \\
1.00\end{array}$ & $\begin{array}{l}1.20 \\
1.00 \\
1.40 \\
1.80\end{array}$ \\
\hline $\begin{array}{l}\text { End-0n Orientation } \\
\text { Multispheres } \\
\text { SNDOPY } \\
\text { RB10 } \\
\text { TEPC }\end{array}$ & $\begin{array}{l}15 \\
16 \\
18 \\
32\end{array}$ & $\begin{array}{l}2.00 \\
= \\
=\end{array}$ & $\begin{array}{l}0.47 \\
0.50 \\
0.56 \\
1.00\end{array}$ & $\begin{array}{l}0.94 \\
1.00 \\
1.13 \\
2.00\end{array}$ \\
\hline
\end{tabular}




\subsection{NEUTRON GENERATOR IN AIR}

The logging tool was placed in a field adjacent to the calibration facility and measured in air. The TEPC, multispheres, and SNOOPY were positioned $72 \mathrm{in.}$ from the neutron source. During the process of disassembling the instrumentation, the TEPC data were inadvertently erased and hence lost. The multisphere and SNOOPY data are presented in Table 11 and plots of neutron flux and dose equivalent spectra are in Figures 34 and 35, respectively.

\section{TABLE 11. Neutron Dose Equivalent Rates for the} Neutron Generator in Air

\begin{tabular}{|c|c|c|c|c|}
\hline Measur ement & $\begin{array}{c}\text { Average Dose } \\
\text { Equivalent } \\
\text { Rate (mrem/hr) } \\
\end{array}$ & $\begin{array}{c}\text { Average } \\
\text { Neutron Energy } \\
\text { (MeV) } \\
\end{array}$ & $\begin{array}{l}\text { Ratio of Dose } \\
\text { Equivalent Rate } \\
\text { Measurement to } \\
\text { TEPC Results } \\
\end{array}$ & $\begin{array}{l}\text { Ratio of Dose } \\
\text { Equivalent Rate } \\
\text { Measurement to } \\
\text { SNOOPY Results } \\
\end{array}$ \\
\hline \multicolumn{5}{|c|}{ Side Orientation } \\
\hline Multispheres & 90 & 7.19 & - & 1.34 \\
\hline SNOOPY & 67 & - & - & 1.00 \\
\hline RB10 & 86 & - & - & 1.28 \\
\hline
\end{tabular}

Neutron Flux Spectrum

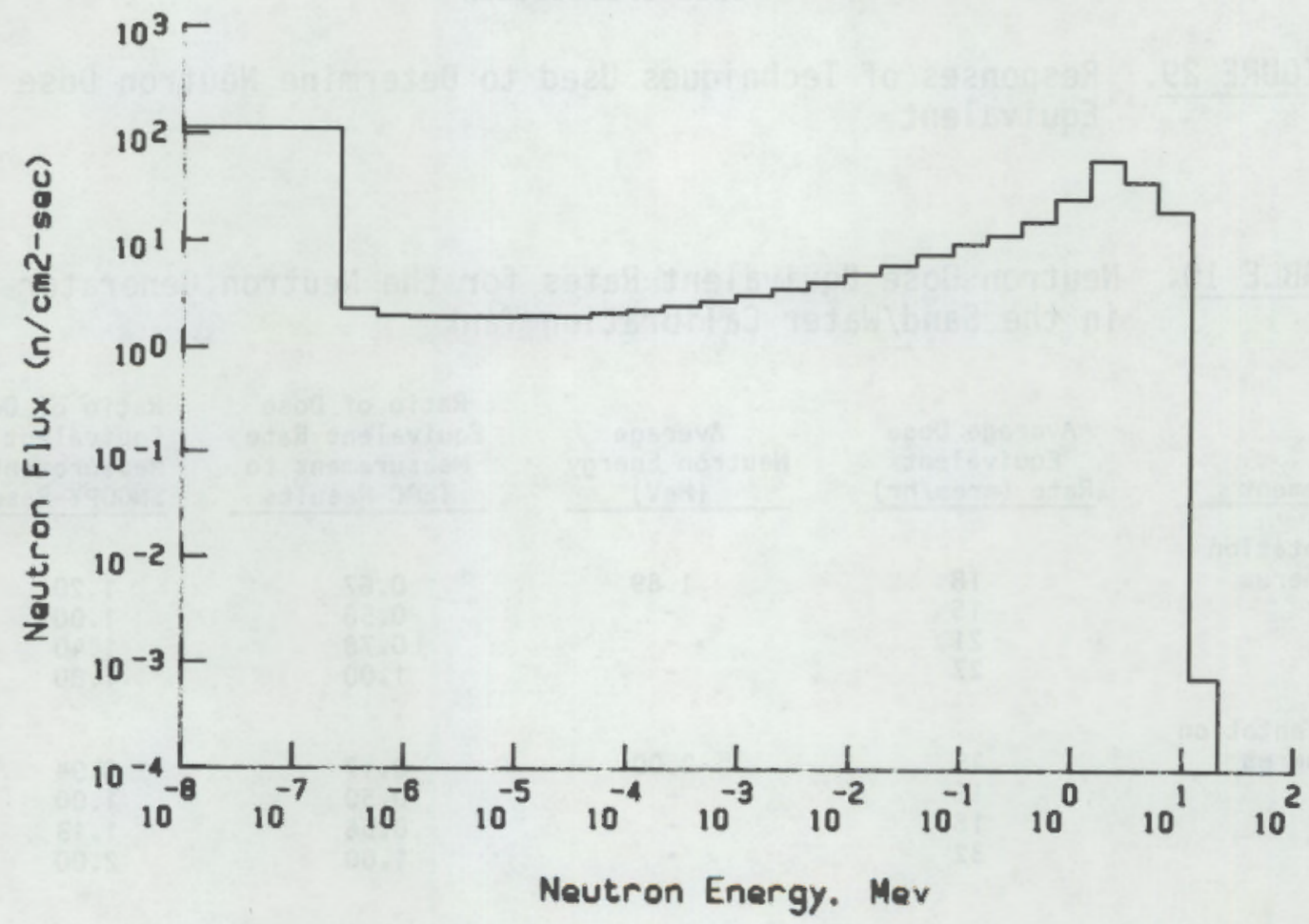

FIGURE 30. DT Generator in Calibrator Tank (side view) 


\section{Neutron Flux Spectrum}

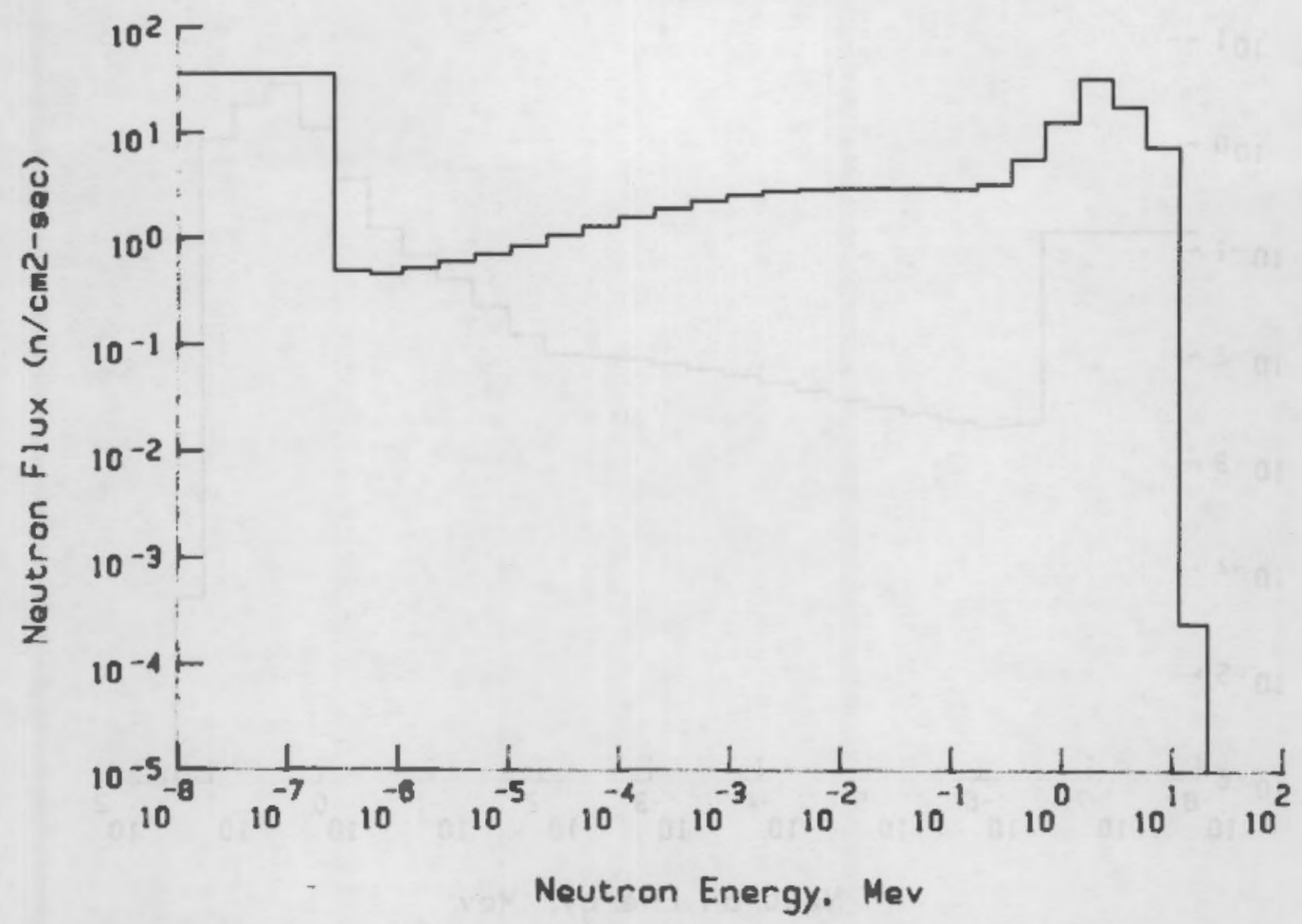

FIGURE 31. DT Generator in Calibrator Tank (front view)

Dose Eq. Spectrum

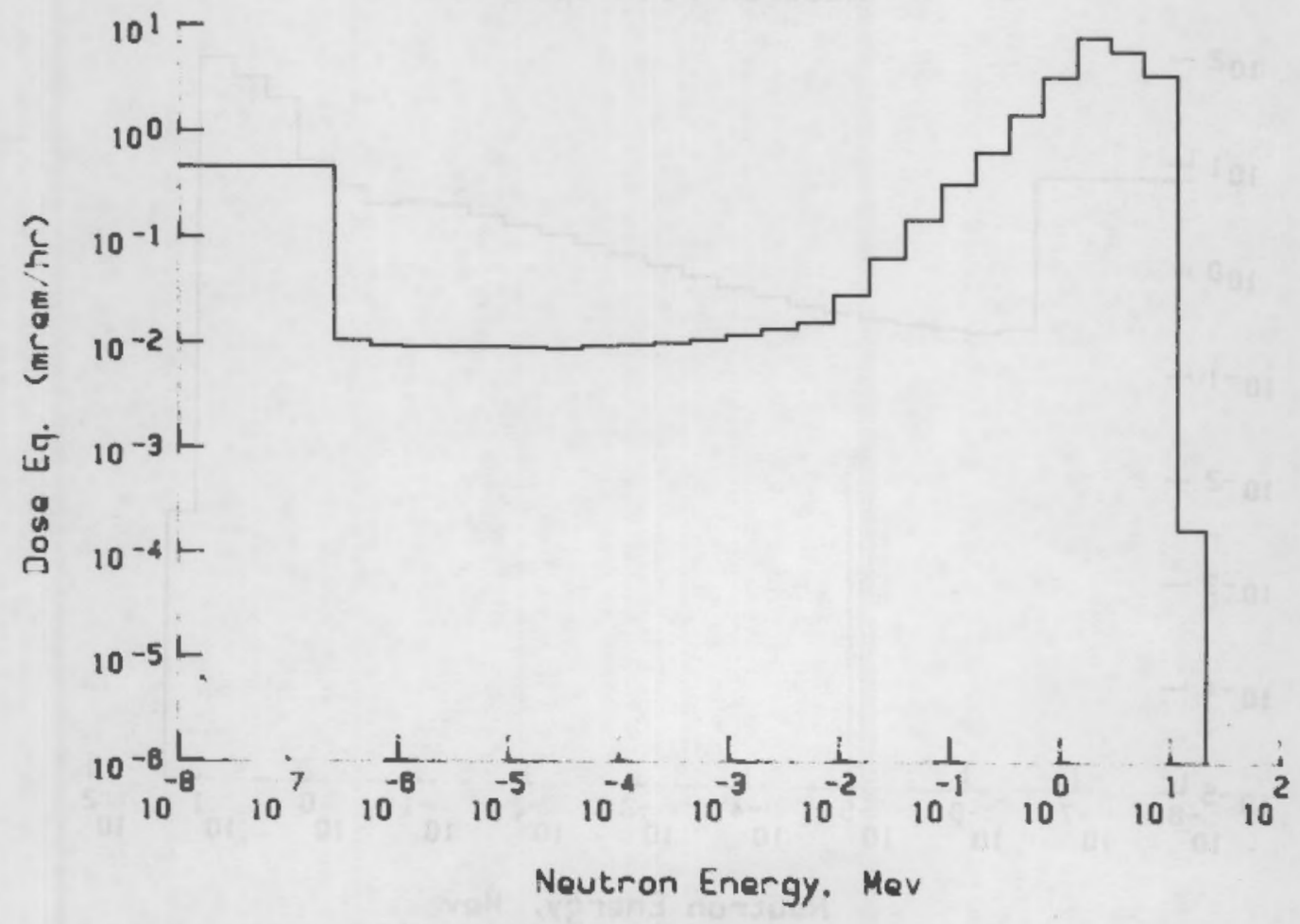

FIGURE 32. DT Generator in Calibrator Tank (side view) 


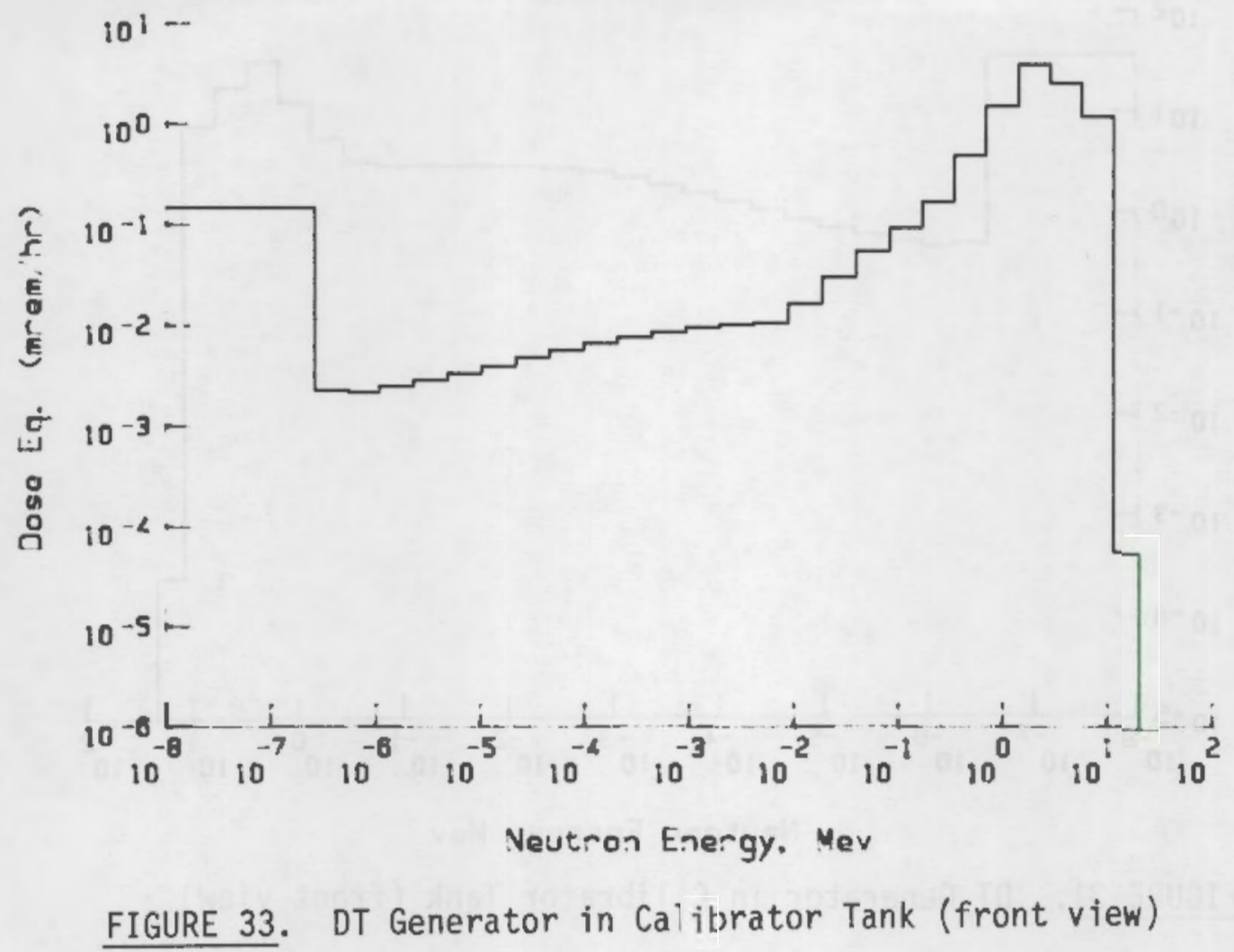

Nautron Flux Spectrum

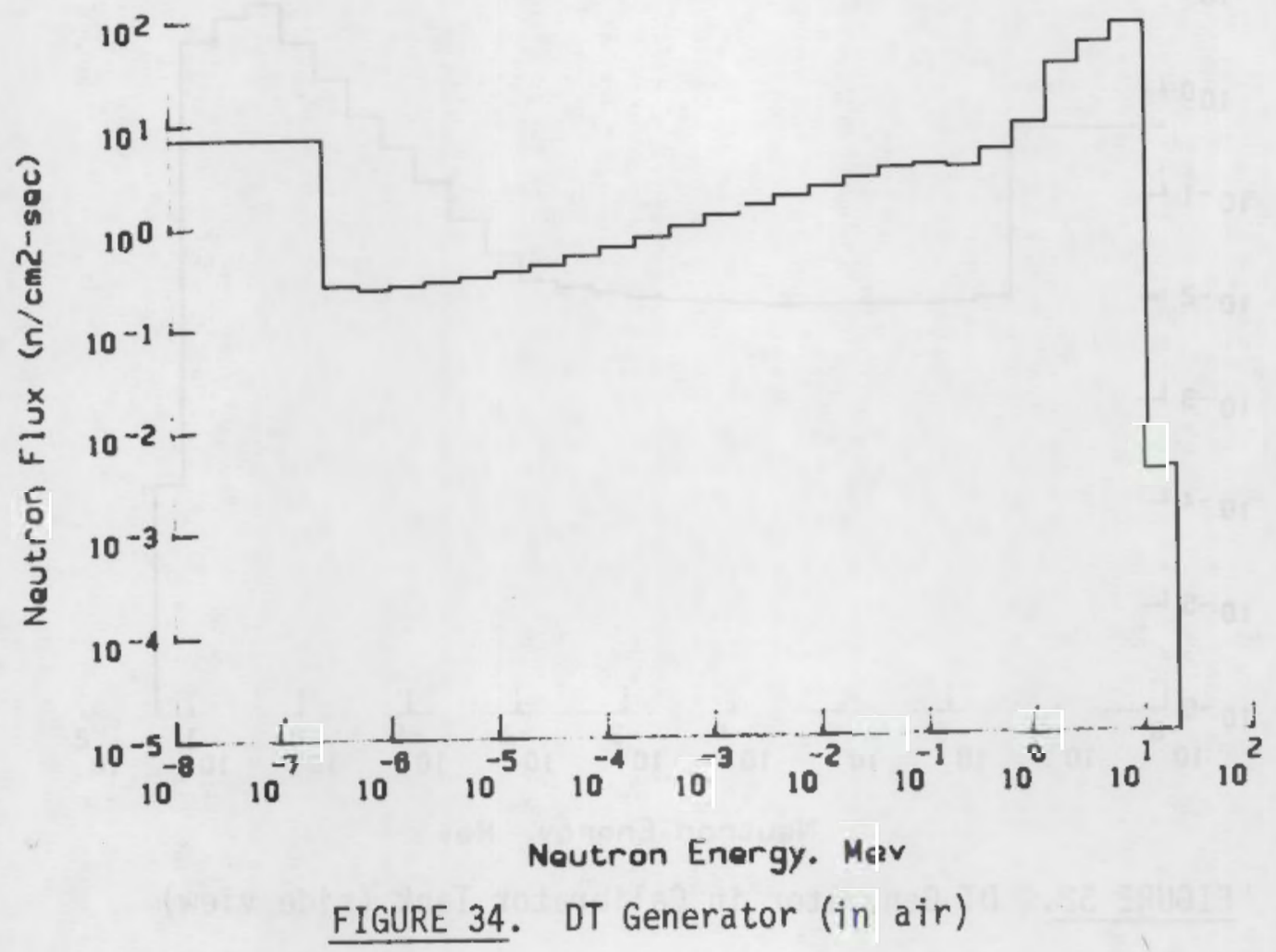




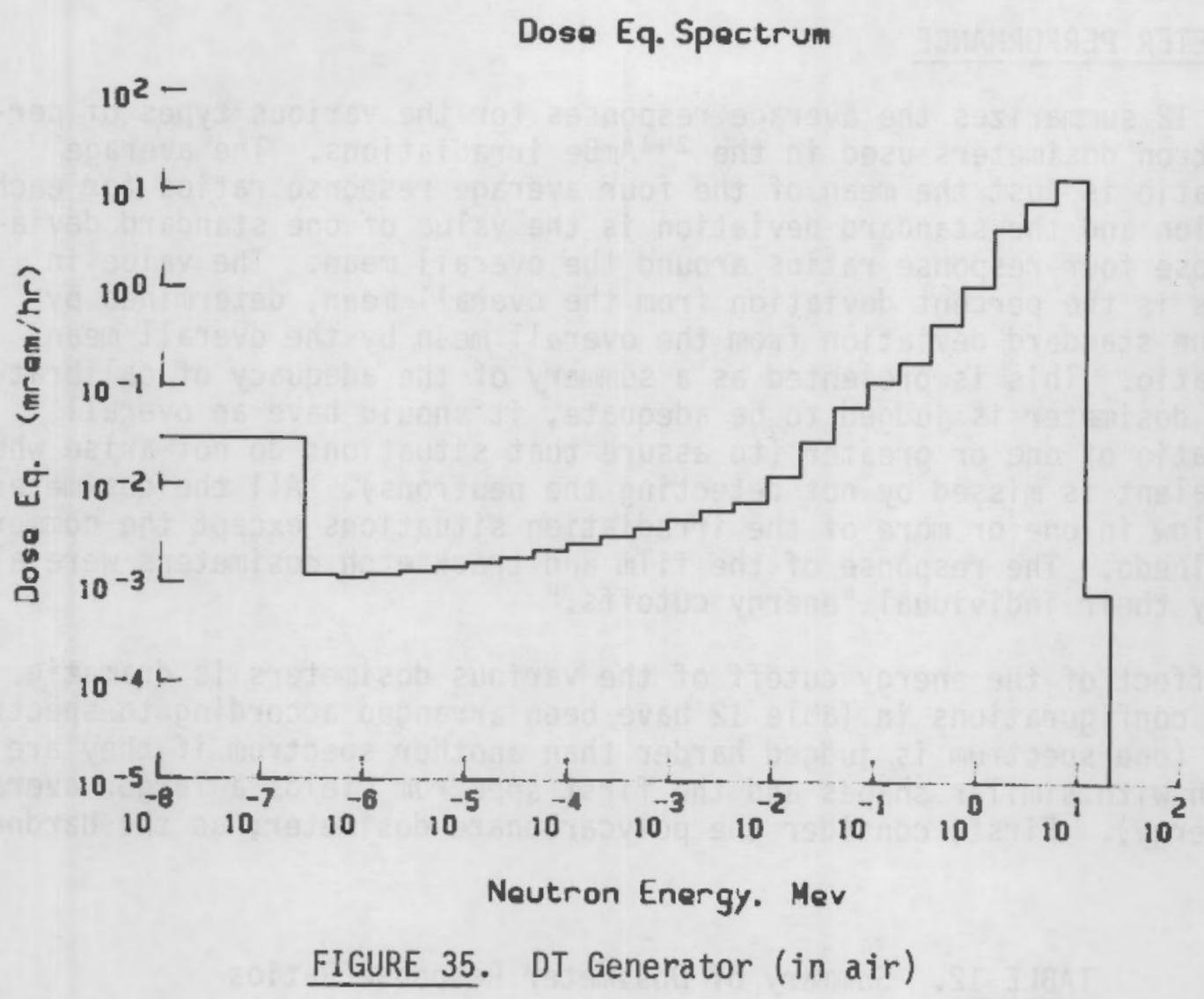




\subsection{CONCLUSIONS}

\subsection{DOSIMETER PERFORMANCE}

Table 12 summarizes the average responses for the various types of personnel neutron dosimeters used in the ${ }^{241} \mathrm{AmBe}$ irradiations. The average response ratio is just the mean of the four average response ratios for each configuration and the standard deviation is the value of one standard deviation of those four response ratios around the overall mean. The value in parentheses is the percent deviation from the overall mean, determined by dividing the standard deviation from the overall mean by the overall mean response ratio. This is presented as a summary of the adequacy of calibration. If a dosimeter is judged to be adequate, it should have an overall response ratio of one or greater (to assure that situations do not arise where dose equivalent is missed by not detecting the neutrons). All the dosimeters responded low in one or more of the irradiation situations except the commercial TLD-albedo. The response of the film and track etch dosimeters were all affected by their individual "energy cutoffs."

The effect of the energy cutoff of the various dosimeters is dramatic. The source configurations in Table 12 have been arranged according to spectral "hardness" (one spectrum is judged harder than another spectrum if they are both smooth with similar shapes and the first spectrum yields a larger average neutron energy). First, consider the polycarbonate dosimeter; as the hardness

TABLE 12. Summary of Dosimeter Response Ratios

\begin{tabular}{|c|c|c|c|c|c|}
\hline \multirow{2}{*}{$\begin{array}{c}\text { Source } \\
\text { Configuration }\end{array}$} & \multicolumn{5}{|c|}{ Ratio of Dosimeter Result to TEPC Result } \\
\hline & NTA & TLD & Comb & CR-39 & Poly \\
\hline 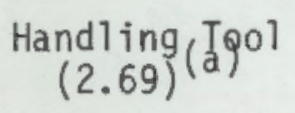 & 0.93 & 1.14 & 0.82 & 0.82 & 1.25 \\
\hline$\underset{(2.26)}{\operatorname{Logging}}{ }^{(29)}$ & 0.56 & 3.22 & 1.71 & 0.66 & 0.78 \\
\hline$\underset{(1.28)^{\text {Shipping }}}{(\text { Cask }}$ & 0.47 & 3.85 & 1.48 & 0.73 & 0.36 \\
\hline $\begin{array}{l}\text { Calibration } \\
\text { Sleeve } \\
\left(0 . \mathrm{Bg}^{\mathrm{a}} \mathrm{a}\right)\end{array}$ & $\underline{0.56}$ & 4.36 & $\underline{0.71}$ & 0.42 & 0.35 \\
\hline $\begin{array}{l}\text { Average } \\
\text { One Standard } \\
\text { Deviation }\end{array}$ & $\begin{array}{l}0.63 \\
0.20(32 \%)\end{array}$ & $\begin{array}{l}3.14 \\
1.41(45 \%)\end{array}$ & $\begin{array}{l}1.18 \\
0.49(42 \%)\end{array}$ & $\begin{array}{l}0.66 \\
0.17(26 \%)\end{array}$ & $\begin{array}{l}0.69 \\
0.43(62 \%)\end{array}$ \\
\hline
\end{tabular}

(a) Average neutron energy in $\mathrm{MeV}$ from multisphere data. 
of the spectrum decreases, the response ratio decreases until a point is reached where further moderation has little effect (i.e. note difference between the "shipping cask" and "calibration sleeve" configurations). At that point, the film is detecting only the neutrons which are not moderated below the cutoff. The same effect is seen for the NTA and CR-39 dosimeters.

The effect of energy dependence in the dosimeters is well illustrated by

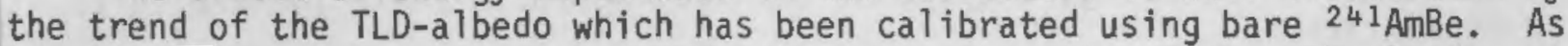
the spectrum becomes more moderated, the response ratio of the TLD-aTbedo increases. The dosimeter is detecting the moderated neutrons, but the output. signal has been enhanced because the probability of interaction has increased in this energy range. Since the output signal is enhanced for moderated neutrons, more dose equivalent will be assigned per unit output signal for irradiations in which the neutron energy spectrum of the source is lower in energy (i.e. more moderated) than that of the calibration source.

\subsection{INSTRUMENTS}

Table 13 summarizes the instrument response data. The SNOOPY remmeter agreed most closely with the TEPC measurements. The responses of the RB10, representing the response of the $9-i n$. remball, were lower overall than the TEPC measurements, a characteristic probably due to the choice of ${ }^{252} \mathrm{Cf}$ as a calibration source. If the response ratios are used to arrive at an internal calibration for the ${ }^{241} \mathrm{AmBe}$ irradiations, the two remmeters may be "recalibrated" and compared. (This type of comparison is possible because both counters operate in a strict count rate-to-dose equivalent rate mode, i.e. the count rate is directly proportional to the dose equivalent rate.) If the "handling tool" configuration is used as representing a bare ${ }^{24}$ AmBe source, and al1 the other response ratios are divided by the ratio from that configuration, the comparison shows that the SNOOPY varies from the TEPC measurement by

\section{TABLE 13. Summary of Instrument Response Ratios}

\begin{tabular}{|c|c|c|c|}
\hline \multicolumn{2}{|c|}{$\begin{array}{l}\text { Source } \\
\text { Configuration }\end{array}$} & \multicolumn{2}{|c|}{$\begin{array}{l}\text { Ratio of Instrument Result } \\
\text { to TEPC Results }\end{array}$} \\
\hline Handling Tool, & $\begin{array}{l}\text { side } \\
\text { end }\end{array}$ & $\begin{array}{l}0.78 \\
1.00\end{array}$ & 0.30 \\
\hline Logging Tool, & side & 0.92 & 0.82 \\
\hline Shipping Cask, & $\begin{array}{l}\text { side } \\
\text { end }\end{array}$ & $\begin{array}{l}1.08 \\
1.00\end{array}$ & $\begin{array}{l}0.77 \\
0.79\end{array}$ \\
\hline Calibration, & $\begin{array}{l}\text { side } \\
\text { end }\end{array}$ & $\begin{array}{l}1.18 \\
0.73 \\
\end{array}$ & $\begin{array}{l}0.87 \\
0.91 \\
\end{array}$ \\
\hline $\begin{array}{l}\text { Average } \\
\text { One Standard De }\end{array}$ & & $\begin{array}{l}0.96 \\
0.16(17 \%)\end{array}$ & $\begin{array}{l}0.75 \\
0.20(26 \%)\end{array}$ \\
\hline
\end{tabular}


a maximum factor of 1.51, while the RB10 varies from the TEPC by a maximum factor of 3.03. The "recalibrated" or normalized responses are presented in Table 14. The difference between the two responses for moderated spectra has been noted in the literature, and these values are consistent with other findings (Schwartz et a1. 1982). The low ratio for the SNOOPY for the calibration sleeve, end, configuration ( 0.73 in Table 13) is considered to be identical to the ratio at the handling, side, configuration ( 0.78 in Table 13) due to counting statistics.

From these data, it may be concluded that the SNOOPY type remmeter provides the best option of remmeters. The fact that the SNOOPY exhibited close agreement with the TEPC, that it is readily available "off the shelf," and it has been used in the radiation protection field for many years in routine operations, all support its adequacy and superiority as a routine neutron monitoring instrument.

\begin{tabular}{|c|c|c|c|}
\hline $\begin{array}{c}\text { Source } \\
\text { Configurat }\end{array}$ & & $\begin{array}{l}\text { Instrument } \\
\text { SNOOPY }\end{array}$ & $\frac{\text { Response Ratios }}{\text { RB10 }}$ \\
\hline Handling Tool, & $\begin{array}{l}\text { side } \\
\text { end }\end{array}$ & $\begin{array}{l}1.00 \\
1.28\end{array}$ & 1.00 \\
\hline Logging Tool, & side & 1.18 & 2.73 \\
\hline Shipping Cask, & $\begin{array}{l}\text { side } \\
\text { end }\end{array}$ & $\begin{array}{l}1.38 \\
1.28\end{array}$ & $\begin{array}{l}2.57 \\
2.63\end{array}$ \\
\hline Calibration, & $\begin{array}{l}\text { side } \\
\text { end }\end{array}$ & $\begin{array}{l}1.51 \\
0.94\end{array}$ & $\begin{array}{l}2.90 \\
3.03\end{array}$ \\
\hline
\end{tabular}




\subsection{RECOMMENDATIONS}

- All the types of dosimeters investigated detected neutrons and yielded a neutron dose equivalent for each irradiation. Commercially available TLD-albedo dosimeter is recommended as the dosimeter of choice because: (1) it always responded high (was not affected by an "energy cutoff"), (2) compared to the other types of dosimeters, it is relatively impervious to the extreme environmental conditions which may be encountered by well-logging personnel, and (3) is readily available from dosimeter processors as a routine and well documented technique for the assignment of dose equivalent to personnel.

- The use of $239 \mathrm{PuBe}$ as a calibration source instead of ${ }^{241} \mathrm{AmBe}$ led to the need for further adjustment of the SNOOPY reading. It is recommended that the ${ }^{241} \mathrm{AmBe}$ source, in the bare configuration, be the calibration source of choice if the well-logging source is ${ }^{241} \mathrm{AmBe}$. Should another source be employed, that particular source, in the bare configuration, should be the calibration source of choice. These comments apply to the TLD-albedo dosimeters as well.

- It is recommended that a single average adjustment factor not be used to adjust dosimeter results in order to apply "field calibrations." It is further recommended that generalized adjustments not be applied to accident situations because of differences in irradiation geometry. 


\subsection{REFERENCES}

Cosack and Lesiecki 1981. Cosack, M., and H. Lesiecki. 1981. "Dependence of the Response of Eight Neutron Dose Equivalent Survey Meters with Regard to the Energy and Direction of Incident Neutrons," Contributed to the Fourth Symposium on Neutron Dosimetry, Neuherberg, Germany.

DePangher and Tochilin 1963. DePangher, J. and E. Tochilin. 1966. "Neutrons From Accelerators." In Vol. 3 of Radiation Dosimetry, Sources, Fields, Measurements and Applications, eds. F. H. Attix and E. Tochilin, Academic Press, New York.

Hankins 1968. Hankins, D. E. 1968. "The Substitution of a $\mathrm{BF}_{3}$ Probe for the LiI Crystal in Neutron Rem-Meters." Health Physics, 14:518.

ICRU 1977. Neutron Dosimetry for Biology and Medicine, ICRU Report 26, International Commission on Radiation Units and Measurements, 7910 Woodmont Avenue, Washington, D.C., 20014, January 1977.

NUREG/CR-1769. Endres, G. W. R., J. M. Aldrich, L. W. Brackenbush, L. G. Faust, R. V. Griffith and D. E. Hankins. 1981. Neutron Dosimetry at Commercial Nuclear Plants, Final Report of Subtask A: Reactor Containment Measurements. NUREG/CR-1769, U.S. Nuclear Regulatory Commission, Washington, D.C.

NUREG/CR-1956. Cummings, F. M., G. W. R. Endres, and L. W. Brackenbush. 1981. Neutron Dosimetry at Commercial Nuclear Plants, Final Report of Subtask B: Dosimeter Response. NUREG/CR-2956, U.S. Nuclear Regulatory Commission, Washington, D.C.

Schwartz et al. 1982. Schwartz, R. B., G. W. R. Endres and F. M. Cummings. 1982. Neutron Dosimeter Performance and Associated Calibrations at Commercial Nuclear Power Plants. NUREG/CR-2233, U.S. Nuclear ReguTatory Commission, Washington, D.C. 
NUREG/CR-3609

PNL-4942

$\mathrm{RL}-\mathrm{RH}$

\section{DISTRIBUTION}

No. of

Copies

OFFSITE

U.S. Nuclear Regulatory Commission Division of Technical Information 7920 Norfolk Avenue

Bethesda, MD 20014

20 Alan Brodsky

U.S. Nuclear Regulatory Commission Office of Radiation Protection 1130 SS, Willste BIdg.

Washington, DC 20555

10 Ed Mott

Dresser Industries

P.0. Box 1407

DCOB 1129B

Houston, TX 77251

2 George 0'Bannion

Nuclear Sources and Services

5838 Dryad

Houston, TX 77035

2 Craig Yoder

R. S. Landauer Jr. Glenwood Science Park

Glenwood, IL 60425
No. of

Copies

2 R. B. Schwartz

U.S. National Bureau of Standards

Quince Orchard Rd.

Gaithersburg, MD 20764

2 Cait Maioney

Radioisotope \& Transportation Division

AECB, Box 1046

Ottowa, Ontario

Canada K1P5S9

\section{ONSITE}

36 Pacific Northwest Laboratory

L. W. Brackenbush

F. M. Cummings (20)

G. W. R. Endres

L. G. Faust

W. A. Glass

D. L. Haggard

G. R. Hoenes

R. I. Scherpelz

J. M. Selby

K. L. Soldat

Technical Information (5)

Publishing Coordination (2) 


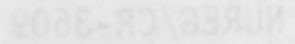

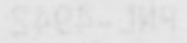

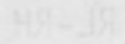


4. TITLE ANO SUgTITLE (Add Volume No., if aporopriato)

Evaluation of Neutron Dosimetry Techniques for Well-Loggin Operations

7. AUTHOR(S) F. M. Cummings, Pac if ic Northwest Laboratory

D. L. Haggard, Pacific Northwest Laboratory

G. W. R. Endres. Pac if ic Northwest Laboratory

9. PERFORMING ORGANIZATION NAME AND MAILING ADDRESS (Inciude zip Code)

Pacific Northwest Laboratory

Richland, Washington 99352

3. RECIPIENT'S ACCESSION NO.

DATE REPORT COMPLETED

\begin{tabular}{l|l}
\hline MONTH & YEAR
\end{tabular}

March

1985

DATE REPORT ISSUED

\begin{tabular}{l|l} 
MONTH & TEAR \\
\hline JUTY
\end{tabular}

July

1985

6. (Leave blank)

8. (Leave bank)

12. SPONSORING ORGANIZATION NAME AND MAILING ADDRESS (Include $Z i p$ Code)

Division of Radiation Programs and Earth Sciences

Office of Nuclear Regulatory Research

U.S. Nuclear Regulatory Commission

Washington, D.C. 20555

10. PROJECT/TASK/WOHK UNIT NO.

13. TYPE OF REPORT

Technical

15. SUPPLEMENTARY NOTES

14. (Leave blank)

16. ABSTRACT (200 words or less)

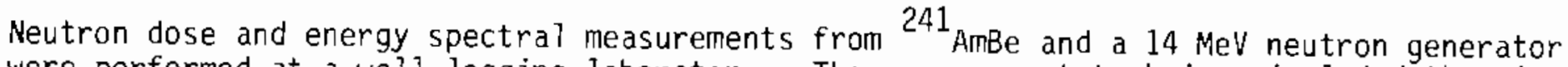
were performed at a weli-logging laboratory. The measurement technique included the tissue equivalent proportional counter, multishpere, two types of remeters and five types of personnel neutron dosimeters. Several source configurations were used to attempt to relate data to field situations. The results of the measurements indicated that the thermoTuminescent albedo dosimeter was the most appropriate personnel neutron dosimeter, and that the most appropriate calibration source would be the source normally employed in the field with the calibration source being used in the unmoderated configuration.

Neutron dosimetry

Neutron spectrometry

well-logging

17b. IDENTIFIERS/OPEN-ENDED TERMS

TITEMENT


